\title{
Justifying Class Action Limits: Parsing the Debates over Ascertainability and Cy Pres
}

\author{
Robert G. Bone*
}

The federal class action has lost its way. It was created fifty years ago in a major revision to Rule 23 that envisioned the class action as a functional aggregation device aimed at promoting litigation efficiency and effective enforcement of substantive rights. Over the past twenty years, however, courts have added technical limitations that restrict the Rule's functional efficacy. This Article examines two such limitations: a strict version of class ascertainability, and restrictions on cy pres relief. These limits are neither mandated by the text of Rule 23 nor supported by a reasonable interpretation of the Rule's language and purpose. Proponents advance functional arguments, but those arguments fail to persuade. This raises an obvious question: why is support so strong when the proffered justifications are so weak? The answer to this question is important for what it reveals about the underlying normative stakes. The strongest arguments for class action limits sound in legitimacy, not functional efficacy. As a result, it is critical to engage the legitimacy arguments on their own terms.

Many of the recent Rule 23 limitations have to do, in one way or another, with the kind of group that can qualify as a litigating "class." In a series of decisions beginning in the late 1990s, the Supreme Court insisted that a group have internal unity, that it be internally "cohesive," before it can be a Rule 23 class. ${ }^{1}$ As I have explained elsewhere, these decisions have resulted in the tightening of Rule 23's commonality and predominance requirements. $^{2}$

This Article examines two other limitations — strict ascertainability and

* G. Rollie White Professor of Law, The University of Texas School of Law. I thank all the participants in the University of Kansas Law School Class Action Symposium and those who attended a UC Hastings College of Law Faculty Colloquium for helpful comments and input. Thanks especially to Laura Hines and Scott Dodson, and also to Michael Davis for his extremely helpful research assistance.

1. See Amchem Prods., Inc. v. Windsor, 521 U.S. 591, 623 (1997) ("The Rule 23(b)(3) predominance inquiry tests whether proposed classes are sufficiently cohesive to warrant adjudication by representation.").

2. Robert G. Bone, The Misguided Search for Class Unity, 82 Geo. WASH. L. ReV. 651, 677-704 (2014) [hereinafter Bone, Misguided Search]. 
limits on cy pres. Ascertainability imposes requirements on class definition. The traditional version of ascertainability is relatively easy to satisfy; it demands only that the boundaries of the class be reasonably clear. ${ }^{3}$ Over the past five years, however, some courts, led by the Third Circuit, have imposed a much stricter version. ${ }^{4}$ They insist not just that the class itself be defined clearly, but also that individuals be identifiable as members of the class in a reliable and administratively feasible way. This strict requirement has potentially severe consequences: it can scuttle small-claim class actions, especially consumer class actions involving low-priced items. ${ }^{5}$

The other limitation involves the cy pres doctrine. This doctrine, which has been around for decades, allows a court to distribute class recovery to a third-party charity when distribution to the class is infeasible or undesirable. ${ }^{6}$ The cy pres doctrine is particularly useful in class actions aggregating small claims. Because class members with only small amounts at stake seldom bother to claim their shares of a settlement fund, it is quite common for a large portion of the fund to be left over after an initial effort to distribute it to the class. Cy pres is a convenient way to dispose of these leftover funds: a court gives the money to a charity engaged in activities that indirectly benefit the class as a whole. ${ }^{7}$

Despite its advantages, cy pres has attracted considerable controversy over the past seven years. Critics argue that it exacerbates agency costs, invites judicial abuse, deprives class members of their property, and violates due process. Some of these critics would go so far as to abolish the practice altogether. ${ }^{8}$ Even supporters of cy pres worry about its unrestricted use, and many favor rather stringent limitations. ${ }^{9}$

3. See infra notes $41-44$ and accompanying text.

4. See, e.g., Carrera v. Bayer Corp., 727 F.3d 300, 307-08 (3d Cir. 2013).

5. See, e.g., Mullins v. Direct Dig., LLC, 795 F.3d 654, 662 (7th Cir. 2015); Myriam Gilles, Class Dismissed: Contemporary Judicial Hostility to Small-Claims Consumer Class Actions, 59 DePaul L. Rev. 305, 307 (2010); Geoffrey C. Shaw, Note, Class Ascertainability, 124 Yale L.J. 2354, 2360, 2377-78 (2015); Daniel Luks, Note, Ascertainability in the Third Circuit: Name that Class Member, 82 Fordham L. Rev. 2359, 2393 (2014); see also infra notes 50-66 and accompanying text (explaining strict ascertainability requirements).

6. See Rhonda Wasserman, Cy Pres in Class Action Settlements, 88 S. CAL. L. REv. 97, 114 18 (2014).

7. Id. at 102-05, 117 (describing circumstances in which cy pres is used to solve the distribution problem and noting that "litigants and courts have enthusiastically latched onto cy pres as a potential solution to the problem of unclaimed class action settlement funds").

8. See, e.g., Martin H. Redish, Peter Julian, \& Samantha Zyontz, Cy Pres Relief and the Pathologies of the Modern Class Action: A Normative and Empirical Analysis, 62 FLA. L. REv. 617, 641-51, 665-66 (2010).

9. See, e.g., Wasserman, supra note 6, at 117-25, 136-62 (discussing problems with cy pres distributions and proposing restrictions); Jay Tidmarsh, Cy Pres and the Optimal Class Action, 82 GEO. WASH. L. REV. 767, 771-73, 784-97 (2014) (discussing problems with cy pres and supporting 
These developments figure prominently in proposed legislation now pending before Congress. ${ }^{10}$ Section 1718(a) of the so-called "Fairness in Class Action Litigation Act" requires a plaintiff to show, as a condition to obtaining class certification, that there is a "reliable and administratively feasible mechanism (a) for the court to determine whether putative class members fall within the class definition and (b) for distributing directly to a substantial majority of class members any monetary relief secured for the class." ${ }^{11}$ This provision would appear to enact a strict version of ascertainability. Moreover, by insisting on substantial distributions to class members, it also restricts the use of cy pres. ${ }^{12}$

At first glance, ascertainability and cy pres might seem to have little in common. They operate at different stages of the litigation - ascertainability is relevant at the class certification stage, while cy pres applies at the remedy stage-and they perform different functions. Nevertheless, the two doctrines are closely linked. Cy pres eases the pressure to require strict ascertainability by making it unnecessary to identify all class members at the remedy stage. ${ }^{13}$ And vice versa: insisting on strict ascertainability at the certification stage makes it possible to identify class members when distributing class recovery at the remedy stage, and thus reduces the need for cy pres.

More importantly, strict ascertainability and restrictions on cy pres are connected normatively. Courts often justify these limiting doctrines in functional terms as promoting the efficiency and fairness of class action litigation. ${ }^{14}$ But as I explain in Parts II and III below, the functional justifications fail in rather obvious ways. In fact, strict ascertainability and restrictions on cy pres have the opposite effect: they undermine the

a reform partly on the ground that it would reduce the need to rely on cy pres).

10. H.R. 985, 115th Cong. (2017).

11. Section 1718(a) provides in full that: "A Federal court shall not issue an order granting certification of a class action seeking monetary relief unless the class is defined with reference to objective criteria and the party seeking to maintain such a class action affirmatively demonstrates that there is a reliable and administratively feasible mechanism (a) for the court to determine whether putative class members fall within the class definition and (b) for distributing directly to a substantial majority of class members any monetary relief secured for the class." Id.

12. The bill passed the House on March 9, 2017, and as of this writing is pending before the Senate Judiciary Committee. See CongRESS.GOV, https://www.congress.gov/bill/115thcongress/house-bill/985/actions (last visited Apr. 3, 2017).

13. If cy pres were readily available, one could imagine a judge saying something like the following: "There's no reason to worry about ascertainability at this early certification stage. If the class recovers, efforts will be made at that time to distribute the proceeds to class members. If it cannot all be distributed because some class members cannot be identified, the court will use cy pres to distribute whatever remains."

14. See infra Parts II and III. 
functional efficacy of the class action. Hence the question: Why does support remain so strong when the functional justifications are so weak?

The answer, I shall argue, is that the restrictive approach is not just about functional efficacy. It is also about adjudicative legitimacy, and the legitimacy-based arguments have greater force. Legitimacy in this context is concerned not so much with whether restrictive rules make the class action work better, but rather with whether they make the class action fit the institution of civil adjudication better. On this view, it is not enough that a class action promotes litigation efficiency, effective enforcement of substantive rights, and other functional goals in a fair and manageable way. The class action must also fit what the judicial system is legitimately supposed to do, and this means that the class suit must qualify as a proper litigating unit - the class must be sufficiently cohesive and have clearly defined boundaries and identifiable class members, and the lawsuit must seek compensation for claimants whose legal rights have been violated.

As I argue below, many of the functional arguments can be reframed as legitimacy arguments without much reworking. And as arguments from legitimacy, they are more difficult to address. This does not necessarily imply that proponents of strict ascertainability and limited cy pres are actually making legitimacy-based arguments cloaked in functional terms. It is impossible to know for sure what they intend. However, it does mean that legitimacy concerns lurk close to the surface.

If I am correct about this, then the debate over class-action limits today is taking place at the wrong normative level. As long as both sides argue in terms of functional goals, they are bound to talk past one another. The way to join issue and make progress is to pitch the debate at the level of adjudicative legitimacy. This is not easy to do. Making sense of legitimacy requires a theory of adjudication, and articulating such a theory is a challenging task. It is quite understandable that courts and commentators would wish to avoid it. Yet it cannot be avoided. The class action forces all of us to confront it squarely.

The body of this Article is divided into four parts. Part I briefly describes the pragmatic and functional vision that shaped the 1966 revision of Rule 23. It also sets the stage for the analysis in subsequent sections by distinguishing between a "functional" argument and an argument based on "adjudicative legitimacy." Part II describes the strict ascertainability requirement and critically examines the conventional arguments used to justify it. These arguments either fail on their own terms or make controversial assumptions that are not adequately defended. Part III does the same for the cy pres doctrine. It describes cy pres and shows that none of the conventional arguments for limiting its application are convincing. 
Part IV then revisits the case for strict ascertainability and limited cy pres. It argues that both developments are better grounded in adjudicative legitimacy than functional efficacy. The concern about adjudicative legitimacy implicates two related beliefs. The first holds that civil adjudication is primarily about compensating injured parties. Deterrence matters, but only if it is accompanied by a substantial compensation benefit. The second belief is closely related to the first. It holds that civil adjudication is about adjudicating and enforcing legal rights belonging to individual right holders. Thus, even if class actions are needed to effectively enforce substantive rights, they can still lack legitimacy when they involve anonymous class members and prioritize deterrence over compensation for rights violations.

These beliefs fit a plausible conception of civil adjudication. Together they describe a core feature that distinguishes adjudication from legislation and administration: its focus on legal rights and on remedies for rights violations. Yet this feature does not demand strict ascertainability or the cy pres limits that have become popular in recent years. Small-claim class actions, such as those enforcing consumer protection laws, share much in common with 23(b)(2) class actions for classwide injunctive relief. Part IV develops this analogy and shows how it can be used to justify the legitimacy of small-claim class actions with unidentifiable class members and liberal use of cy pres.

\section{THE 1966 REVISION OF RULE 23}

In 1966, the Advisory Committee on Civil Rules revised Rule 23 to replace a formalistic and relatively narrow representative suit device with a new and broader class action procedure structured along functional lines. At the heart of this revision was a normative shift from rights-based formalism to policy-based functionalism. The following discussion briefly describes this shift and then defines the distinction between a "functional argument" and one based on "legitimacy," a distinction that plays a key role in the rest of the analysis.

\section{A. A Functional Rule 23}

As is well known, the 1938 Advisory Committee aimed for a simple and uniform set of procedural rules designed to adjudicate cases in an efficient, "streamlined" way based on the facts and the relevant law. ${ }^{15}$ In keeping

15. See Robert G. Bone, Mapping the Boundaries of the Dispute: Conceptions of Ideal 
with this broad goal, the Committee rejected the technicalities of common law and code procedure and crafted the new Federal Rules of Civil Procedure (FRCP) along functional and pragmatic lines. ${ }^{16}$ For example, the FRCP simplified pleading so that cases could be decided on the merits, expanded permissive joinder so that courts could entertain efficient litigating units, instituted broad discovery so that parties could ferret out all the relevant facts and evidence, and innovated with summary judgment and the pretrial conference. ${ }^{17}$ But not all of the new Rules were designed functionally. The Committee chose a different approach for three party structure rules: Rule 19 (compulsory joinder), Rule 24 (intervention), and Rule 23 (class action). These three Rules retained the formalistic character and limited scope of their nineteenth and early twentieth century counterparts. ${ }^{18}$

In particular, Rule 23 was organized around formal categories of legal rights. ${ }^{19}$ This structure was meant to track distinctions among different types of class actions recognized in the nineteenth and early twentieth

Lawsuit Structure from the Field Code to the Federal Rules, 89 COLUM. L. REV. 1, 78-98 (1988) [hereinafter Bone, Mapping] (tracing the history of the twentieth century reform movement).

16. See id. Charles Clark, the Reporter to the 1938 Advisory Committee and chief architect of the 1938 Federal Rules, was a moderate legal realist and pragmatist, as were many of the other influential procedure reformers of the period. It should not be surprising then that the new Federal Rules of Civil Procedure reflected the realist's commitment to pragmatic functionalism. See id.; see also David Marcus, The Federal Rules of Civil Procedure and Legal Realism as a Jurisprudence of Law Reform, 44 GA. L. REV. 433, 453-70 (2010) (arguing that Charles Clark was a legal realist and that drafting the Federal Rules was a realist project).

17. See Bone, Mapping, supra note 15, at 98-107; Stephen N. Subrin, Fishing Expeditions Allowed: The Historical Background of the 1938 Federal Discovery Rules, 39 B.C. L. REV. 691, 691, 728-29 (1998).

18. It is not clear why the Advisory Committee rejected a functional approach to these Rules. See Bone, Mapping, supra note 15, at 107-14 (discussing this question in connection with Rule 19). One possibility is that the Committee's focus was elsewhere. Its primary concern was to eliminate the unnecessary cost and delay of code and common law procedure and to enable decisions based on the facts rather than on technicalities. This focused Committee attention on the technical pleading requirements, narrow permissive joinder rules, and limited discovery of code and common law procedure. The Committee may have thought that the representative suit, compulsory joinder, and intervention rules did not implicate these concerns in a central enough way. Moreover, at least the representative suit was used so rarely that the Committee may also have thought it did not warrant much attention. Finally, representative suits, compulsory joinder, and intervention all have serious effects on litigant autonomy not just procedural efficiency, and the Advisory Committee may not have known how to address the resulting fairness concerns. See id.

19. See FED. R. CIV. P. 23(a) (1938) (distinguishing among "joint," "common," "secondary," and "several" rights). Also, Rule 19 relied on the nineteenth century concept of "joint interest" and the formalistic category of "indispensable" parties. FED. R. CIV. P. 19 (1938); Bone, Mapping, supra note 15, at 107-14 (discussing Rule 19). And Rule 24 limited intervention narrowly to cases of preclusion and property distribution. See FED. R. CIV. P. 24(a) (1938); FED. R. CIV. P. 24, advisory committee's note to 1938 rules ("This rule amplifies and restates the present federal practice at law and in equity."). 
centuries. $^{20}$ "Joint" or "common" (or "secondary") rights supported what had previously been called the true class action; "several" rights supported hybrid class actions insofar as the object of the suit was to affect specific property, and "several" rights with a common question supported spurious class actions. ${ }^{21}$ Moreover, the preclusive effects of these three types of class action tracked the established representative suit precedent. True class actions bound class members in the way the modern class action does. ${ }^{22}$ Hybrid class actions bound class members only with respect to the property involved in the suit. ${ }^{23}$ And spurious class actions bound only those class members who chose to intervene. ${ }^{24}$

Even though many federal judges found these formal rights-based distinctions difficult to understand and apply, the 1938 version of Rule 23 remained in effect for twenty-eight years. ${ }^{25}$ In 1966, the Advisory Committee overhauled Rule 23 (along with Rules 19 and 24) to bring it more in line with the FRCP's functional vision. ${ }^{26}$ The 1966 revision eliminated all reference to formal rights-categories and distinguished the different types of class action by the policy reasons for class treatment. Moreover, it turned the class action into a powerful preclusion device designed to bind all class members to the judgment. ${ }^{27}$

20. See FED. R. CIV. P. 23 advisory committee's note to 1938 amendment ("This is a substantial restatement of [former] Equity Rule 38 (Representatives of Class) as that rule has been construed."); James Wm. Moore \& Marcus Cohn, Federal Class Actions, 32 ILL. L. REV. 307, 325 (1937); see also Robert G. Bone, Personal and Impersonal Litigative Forms: Reconceiving the History of Adjudicative Representation, 70 B.U. L. REV. 213, 288-90 (1990) [hereinafter Bone, Personal and Impersonal] (review essay) (describing parallels between Rule 23's structure and early class actions, but also noting that the new Rule departed from precedent in significant ways).

21. See James Wm. Moore \& Marcus Cohn, Federal Class Actions_-Jurisdiction and Effect of Judgment, 32 ILL. L. REV. 555, 555 (1938). Moore and Cohn illustrated the distinctions with examples of nineteenth and early twentieth century representative suits. Id. at 556-63. See also 1 Thomas AtKins Street, Federal Equity Practice $\S \S 547-49$ (1909) (distinguishing between true and hybrid suits).

22. See Moore \& Cohn, supra note 21 at 556-63.

23. Id.

24. Id.

25. See Zechariah Chafee, Jr., Some Problems of Equity, in ThE Thomas M. CoOLEY LECTURES 251 (2d ser. 1950). Courts applying the original Rule 23 had great difficulty distinguishing between joint, common, and several rights, and stretched and twisted these concepts to generate the types of preclusive effect they thought desirable. See id.; FED. R. CIV. P. 23 advisory committee's note to 1966 amendment.

26. See FED. R. CIV. P. 23 (1966). The 1966 Advisory Committee also eliminated the references to joint interest and indispensable parties in Rule 19 and rewrote Rule 19 to identify the practical reasons for requiring joinder of an absentee. See FED. R. CIV. P. 19 advisory committee's note to 1966 amendment. Moreover, the Committee expanded the availability of intervention and tied intervention as of right to situations where the intervenor's interests would be seriously harmed if she were not allowed to intervene. See FED. R. CIV. P. 24, advisory committee's note to 1966 amendment.

27. See FED. R. CIV. P. 23 advisory committee's note to 1966 amendment; 7AA CHARLES 
In keeping with these goals, the 1966 drafters targeted cases where there were strong functional reasons to preclude class members. ${ }^{28}$ Thus, Rule 23(b)(1) authorizes a class action to prevent unfair externalities produced by individual litigation, such as the unfair distributional consequences of allowing multiple plaintiffs to sue individually for a limited fund. ${ }^{29}$ Rule 23(b)(2) authorizes a class action to promote remedial efficacy, such as securing the remedial advantages of a classwide injunction. ${ }^{30}$ Finally, Rule 23(b)(3), the most ambitious innovation of the 1966 Rule, replaces the old spurious class action with a much more expansive aggregation device aimed at improving litigation efficiency and decisional consistency, ${ }^{31}$ as well as enabling private enforcement of the substantive law. ${ }^{32}$

The 1966 revision also created a new certification procedure that delegated responsibility to the trial judge to ensure that Rule 23's requirements were satisfied. ${ }^{33}$ In addition, the new Rule gave the trial judge

Alan Wright, Arthur R. Miller, \& Mary Kay Kane, Federal Practice and Procedure $\S$ 1789 ( 3 d ed. 2005). Even though the 1966 Rule was intended to preclude class members, the 1966 advisory committee made clear that the class action court could not prejudge res judicata effect. See FED. R. CIV. P. 23 advisory committee's note to 1966 amendment. Whether a class member would be precluded by a class judgment was for a subsequent court to decide if a class member tried to sue again. See id.

28. See, e.g., Benjamin Kaplan, A Prefatory Note, 10 B.C. InDus. \& COM. L. REV. 497, 497 (1968) ("The reform of Rule 23 was intended to shake the law of class actions free of abstract categories contrived from such bloodless words as 'joint,' 'common,' and 'several,' and to rebuild the law on functional lines responsive to those recurrent life patterns which call for mass litigation through representative parties.").

29. FED. R. CIV. P. 23(b)(1); see 7AA WRIGHT ET AL., supra note 27, § 1774, at 30-35 (3d ed. 2005). When many individuals have claims on a fixed fund that is too small to pay all the claims, Rule 23(b)(1) can be used to force the claimants to litigate together so the court can equitably allocate the limited fund among them and bind everyone to that result. See id.

30. FED. R. CIV. P. 23(b)(2); see David Marcus, Flawed but Noble: Desegregation Litigation and Its Implications for the Modern Class Action, 63 FLA. L. REV. 657, 660-61, 695-711 (2011) (explaining that the 1966 committee drafted (b)(2) to facilitate broad injunctive relief in desegregation suits). A class action matches the scope of the lawsuit to the scope of the relief sought and ensures that all those affected can enforce the decree. See id. at 679-80.

31. See, e.g., Benjamin Kaplan, Continuing Work of the Civil Committee: 1966 Amendments of the Federal Rules of Civil Procedure (I), 81 HARV. L. REV. 356, 390 (1967) (noting that the new (b)(3) aims "to get at the cases where a class action promises important advantages of economy of effort and uniformity of result without undue dilution of procedural safeguards for members of the class or for the opposing party").

32. See id. at 397-98; Kaplan, supra note 28, at 497-500. In addition, the (b)(3) class action improves the quality of outcomes by helping to equalize economy-of-scale advantages, and thus litigating power, across the party line. See, e.g., David Rosenberg \& Kathryn E. Spier, Incentives to Invest in Litigation and the Superiority of the Class Action, 6 J. LEgAL ANALYSIS 305, 347-48 (2014) (noting that the class action nullifies the defendant's opportunity to gain more from investment and scale economies). However, it is not clear that this was an explicit goal of the 1966 committee.

33. See FED. R. CIV. P. 23(c)(1) (1966). At the time, Rule 23(c)(1) provided that "the court shall determine by order whether [the suit] is to be ... maintained [as a class action]." Id. See generally Tobias Barrington Wolff, Discretion in Class Certification, 162 U. PA. L. REV. 1897, 
tools to help manage the class action fairly and efficiently. ${ }^{34}$ The Committee also worried about the due process rights of absent class members. To address this concern, it included 23(a)(4), which instructs the judge to determine that class representatives and the class attorney will adequately represent the interests of absent class members, and 23(a)(3), which demands that the representative's claims be typical of the claims of class members. ${ }^{35}$ And for (b)(3) damages class actions, the Committee also added a special due process safeguard: it gave class members a right to opt out of the class and avoid its binding effect. ${ }^{36}$

The important point is that the 1966 drafters envisioned the Rule 23 class action as a functional aggregation device aimed at improving the quality of litigation outcomes and saving litigation costs. Since it bound absent class members, the new device had to comply with due process requirements. But the due process protections included in Rule 23 left wide room for class aggregation.

Since the late 1990s, however, courts have made it more difficult to certify class actions that seem quite sensible on functional grounds. They have done so by construing existing certification requirements narrowly and imposing additional requirements beyond those explicitly mentioned in Rule $23 .^{37}$ In a previous article, I examined one of these additional requirements, the necessity that a class be "cohesive." 38 This Article examines two others - strict ascertainability and restrictions on the use of cy pres.

1911-16 (2014) (describing growing reliance on discretion in the wake of 1966 Rule 23).

34. FED. R. CIV. P. 23(d) (1966) (listing some procedural tools for managing class actions); see also FED. R. CIV. P. 23(c)(4) (1966) (authorizing issue classes and subclasses); FED. R. CIV. P. 23(e) (requiring judicial review and approval of class settlements).

35. See FED. R. CIV. P. 23(a)(3)-(4). In the famous 1940 case Hansberry v. Lee, the Supreme Court recognized adequate representation of interests as a basis for binding nonparties. 311 U.S. 32, 42-43 (1940).

36. See FED. R. Civ. P. 23(c)(2) (1966). The 1966 version of Rule 23 added an additional safeguard by mandating notice to the class in a (b)(3) class action and requiring that the notice instruct class members that they have a right to opt out. $I d$. The current version of Rule 23 does the same thing but with revised language. FED. R. CIV. P. 23(c)(2)(B).

37. See Robert H. Klonoff, The Decline of Class Actions, 90 WASH. U. L. REv. 729, 745-823 (2013) (providing an overview of the many court imposed restrictions on class actions). But see Robert H. Klonoff, A Respite from the Decline, N.Y.U. L. REV. (forthcoming Oct. 2017), https://papers.ssrn.com/sol3/papers.cfm?abstract_id=2881484 (arguing that the restrictive trend has subsided a bit since 2013).

38. In 1997, the Supreme Court recognized a separate class cohesion requirement. See Amchem Prods., Inc. v. Windsor, 521 U.S. 591, 623 (1997). As I have argued elsewhere, this interpretation of predominance is not supported by the history of Rule 23 or required by the efficiency and law enforcement goals of the (b)(3) class action. Bone, Misguided Search, supra note 2, at 678-79. In fact, the Amchem Court justified its cohesion requirement on grounds of adjudicative legitimacy, and ever since the Amchem decision, class cohesion, in one way or another, has influenced a number of restrictive class action developments, including a stricter approach to (b)(3) predominance, denying monetary relief as part of a (b)(2) class action, and restricting the 
These two requirements make it more difficult for plaintiffs to obtain certification of (b)(3) class actions that aggregate claims too small to justify individual suits. The primary purpose of a small-claim class action is to enable private enforcement of the substantive law and ensure that wrongdoers whose activities create small amounts of harm to many individuals are held accountable for their wrongful conduct. ${ }^{39}$ As we shall see, neither strict ascertainability nor substantial limits on cy pres make functional sense in these cases; nor are they required by due process. This then frames the puzzle: Why have they garnered the support they have?

\section{B. Clarifying Terminology}

Before proceeding, it will be useful to clarify some terminology. Throughout the following discussion, I contrast "functional" arguments with arguments based on "adjudicative legitimacy." A functional argument focuses on the goals of the class action or the demands of due process. By contrast, a legitimacy argument focuses on whether a class action of the type requested is a proper form of procedure for courts. The class action might do a fine job of serving functional goals and be acceptable to all class members, yet still not be legitimate for the institution of civil adjudication.

Legitimacy arguments collapse into functional arguments when the theory of adjudicative legitimacy is functional in the same way. But they diverge when legitimacy demands something more. For example, certification of a small-claim class action despite unidentifiable class members and with liberal use of cy pres can effectively deter violations of the substantive law without adversely affecting absentee participation (since absentees have too little at stake to be interested in participating). Yet this type of class action can still raise legitimacy concerns. A critic might worry that a class action with anonymous members, a deterrence focus, and no meaningful compensatory purpose is too different from established forms of litigation to qualify as a proper mode of civil adjudication.

certification of issue classes. Id. at 677-704.

39. See Butler v. Sears, Roebuck \& Co., 702 F.3d 359, 362 (7th Cir. 2012), vacated, 133 S. Ct. 2768 (2013); Jonathan R. Macey \& Geoffrey P. Miller, The Plaintiffs' Attorney's Role in Class Action and Derivative Litigation: Economic Analysis and Recommendations for Reform, $58 \mathrm{U}$. CHI. L. REV. 1, 7-11 (1991). 


\section{ASCERTAINABILITY}

The following discussion focuses on the ascertainability requirement. It first distinguishes between the traditional version and the newer and much stricter version. It then critically examines the policy reasons advanced to support the stricter version and explains why those reasons fail.

\section{A. Strict versus Weak Ascertainability}

It is well accepted that a class must be ascertainable before it can be certified. $^{40}$ In the past, the ascertainability requirement has been relatively easy to satisfy. In recent years, however, courts have adopted a much stricter version. I shall refer to the traditional requirement as "weak ascertainability" and the new requirement as "strict ascertainability." Weak ascertainability focuses on ascertaining the dimensions of the class itself; strict ascertainability focuses on ascertaining the identities of individual class members.

More specifically, weak ascertainability imposes three constraints on how a class is defined. First, the class definition must be clear and definite enough so that the boundaries of the class are apparent and individuals can determine whether or not they are members. ${ }^{42}$ Second, the class must be defined by reference to objective criteria rather than subjective state-of-mind factors. ${ }^{43}$ Third, the class must be defined in terms that do not refer to success on merits-related issues. ${ }^{44}$

There are sensible policy reasons for each of these three requirements. A clearly defined class assists plaintiffs in deciding whether or not they are members for purposes of exercising opt-out rights, and also helps the

40. See Mullins v. Direct Dig., LLC, 795 F.3d 654, 657 (7th Cir. 2015) ("We and other courts have long recognized an implicit requirement under Rule 23 that a class must be defined clearly and that membership be defined by objective criteria ....").

41. See id. at 659,661 (referring to a "weak" version and a "more stringent" version).

42. See id. at 659-60; 7AA WRIGHT ET AL., supra note 27, § 1760, at 136-42. Rule $23(\mathrm{c})(1)(\mathrm{B})$ also requires that the court, when certifying a class action, "must define the class and the class claims, issues, or defenses." FED. R. CIV. P. 23(c)(1)(B); see also Wachtel v. Guardian Life Ins. Co. of Am., 453 F.3d 179, 184-85 (3d Cir. 2006) (holding that 23(c)(1)(B) "requires district courts to include in class certification orders a clear and complete summary of those claims, issues, or defenses subject to class treatment" and that an appellate court reviewing compliance with 23(c)(1)(B) should inquire into "whether the precise parameters defining the class and a complete list of the claims, issues, or defenses... are readily discernible from" the certification order or memorandum).

43. See 5 J. Solovy, R. Marmer, T. Chorvat, and D. Feingerg, Moore's Federal Practice, § 23.21[3][a] (3d ed. 2011) [hereinafter MOORE’s Federal PraCtice].

44. See id. $\$ 23.21[3][\mathrm{c}]$. 
defendant evaluate its liability exposure. ${ }^{45}$ Moreover, insisting on objective criteria facilitates later preclusion determinations. For example, if a class were defined as all persons "discouraged from applying for assistance," a later court deciding the preclusive effect of the class judgment would have to determine whether the plaintiff was discouraged from applying, which would likely involve costly evidence production and hearings. ${ }^{46}$ Finally, the rule prohibiting definitions based on merits-related success avoids "failsafe" classes, in which class members are bound only if the class wins. ${ }^{47}$ Fail-safe classes are thought to be unfair to the defendant because the class action provides no preclusion benefit for the defendant when it prevails. ${ }^{48}$

From a functional perspective, these requirements make sense only if they are flexibly applied. There are costs as well as benefits to a sharper, more objective, and less merits-dependent class definition, especially when it is not easy to improve the existing definition in these ways. For this reason, the requisite degree of ascertainability should be determined by a cost-benefit balance. Ascertainability should depend on the policies favoring class action treatment, the benefits of providing a more precise, objective, or merits-neutral class definition, and the difficulty of improving the class definition along these lines. ${ }^{49}$ Weak ascertainability allows for this sort of analysis.

Strict ascertainability works differently. It requires that the named plaintiff show, by a preponderance of the evidence, that there is a reliable and administratively feasible way to ascertain whether an individual is in fact a member of the class. ${ }^{50}$ It is not enough that a putative class member

45. See Shaw, supra note 5, at 2377. For example, a class defined in terms of "young people" would likely be too indefinite, since an eighteen-year old could not be certain whether she was in the class. Id.

46. Simer v. Rios, 661 F.2d 655, 669-70 (7th Cir. 1981).

47. An example is a class defined to include all defrauded consumers. If the class loses and the court finds that no consumer has been defrauded, then the class, as defined, has no members and the class judgment binds only the named plaintiffs.

48. 2 William B. Rubenstein et Al., Newberg on Class Actions $§ 3: 6$ (5th ed. 2012) [hereinafter NEWBERG ON CLASS ACTIONS].

49. The requisite degree of clarity and definiteness should depend, in part, on the court's ability to manage the class action as the plaintiff has defined it and the benefits and costs of a more precise definition, including the likelihood that class members might want to opt out. The rule against subjective criteria should turn on the ease of defining the class in objective terms and the consequences of a subjective definition. The balance for fail-safe classes rarely makes a difference because a class can almost always be defined independent of merits success. But if it were difficult to do so, a fail-safe class might be tolerated when the policies served by class certification are strong enough and the adverse consequences of a fail-safe class not terribly serious. See id. § 3:6 (noting that some courts take a more flexible approach to fail-safe class definitions).

50. See, e.g., Karhu v. Vital Pharms., Inc., 621 Fed. Appx. 945, 947-48 (11th Cir. 2015); Carrera v. Bayer Corp., 727 F.3d 300, 305-06 (3d Cir. 2013); Xavier v. Philip Morris USA Inc., 787 F. Supp. 2d 1075, 1089-90 (N.D. Cal. 2011). 
can determine membership for herself. ${ }^{51}$ The court and the defendant must be able to verify membership in a reliable and cost-effective way. ${ }^{52}$ Moreover, this requirement is not flexible in the way an ascertainability requirement should be. Instead, it is mandatory for certification and not subject to cost-benefit balancing.

As a practical matter, the most salient difference between the two types of ascertainability involves the kind of evidence required to prove class membership. Strict ascertainability excludes self-serving affidavits unless the plaintiff is able to show a sufficiently reliable method for verifying their accuracy. ${ }^{53}$ Weak ascertainability is much less demanding. To satisfy weak ascertainability, it is rarely necessary at the certification stage to prove the existence of a method for identifying class members. ${ }^{54}$

To illustrate strict ascertainability, consider the facts of Carrera $v$. Bayer Corp., the Third Circuit case that is widely recognized as the first to clearly articulate a strict ascertainability rule. ${ }^{55}$ Bayer sold a multivitamin and dietary supplement known as WeightSmart and advertised its benefits for increasing metabolism. ${ }^{56}$ The named plaintiff, Gabriel Carrera, sued on a false and deceptive advertising claim, alleging that WeightSmart did not confer the metabolism benefits that Bayer claimed for it. ${ }^{57}$ She sought

51. See, e.g., Karhu, 621 Fed. Appx. at 948.

52. It is not always easy to determine whether a court is applying strict or weak ascertainability. The problem is partly semantic. Courts sometimes express the ascertainability requirement in terms of the feasibility of determining membership without making clear who it is that is supposed to be able to determine membership - the class members themselves and a subsequent court applying preclusion (supporting weak ascertainability), or the class action court and the class defendant (supporting strict ascertainability). Also, a class definition can fail both tests, in which case the court does not have to choose between them. See, e.g., Brecher v. Republic of Argentina, 806 F.3d 22, 24-25 (2d Cir. 2015) ("clarify[ing] that the touchstone of ascertainability is whether the class is "sufficiently definite so that it is administratively feasible for the court to determine whether a particular individual is a member," but denying certification on grounds that fit weak ascertainability) (citations omitted).

53. See, e.g., Karhu, 621 Fed. Appx. at 949. Thus, strict ascertainability does not rule out affidavits categorically. See id. However, as we shall see, it sets a high standard for verifying the truthfulness of the assertions in an affidavit, a standard that is often difficult to meet.

54. And when it is, a method relying on class member affidavits will normally suffice. Some courts that subscribe to weak ascertainability worry about affidavits when there are special reasons to doubt the memory of class members, such as when the lawsuit targets only one of several different varieties of the same brand and consumers are unlikely to recall which variety they purchased. See, e.g., In re Dial Complete Mktg. \& Sales Practices Litig., 312 F.R.D. 36, 52 (D.N.H. 2015); Kosta v. Del Monte Foods, Inc., 308 F.R.D. 217, 227-29 (N.D. Ca. 2015).

55. Carrera v. Bayer Corp., 727 F.3d 300 (3d Cir. 2013).

56. Id. at 304. A package of fifty tablets sold for $\$ 8.99$ and a package of 100 tablets for \$16.99. Id.

57. $I d$. 
damages on behalf of a class defined as "all persons who purchased WeightSmart in Florida."

Bayer opposed class certification on the ground, among others, that the class definition did not meet the ascertainability requirement. ${ }^{59}$ Carrera's class definition plainly satisfied weak ascertainability. The definition was clear and definite enough: a consumer either purchased WeightSmart in Florida or did not. Any WeightSmart consumer in Florida who wanted to opt out, for example, could easily tell whether she was a member of the class. Moreover, it was sufficiently objective: membership did not depend on a consumer's subjective state of mind. And it was wholly independent of the merits: class members were clearly bound whether they won or lost.

Nevertheless, the Third Circuit held that the class definition did not satisfy strict ascertainability, at least not without additional evidence showing a feasible and reliable way to identify class members. ${ }^{60}$ Bayer sold only to retailers and thus had no information about which consumers purchased WeightSmart. ${ }^{61}$ Moreover, retailers did not keep complete records of WeightSmart purchasers. ${ }^{62}$ And most WeightSmart consumers would not have retained their receipts. ${ }^{63}$ The plaintiff, Carrera, suggested that class members could file their own affidavits attesting to the fact that they purchased WeightSmart, but the Third Circuit rejected this approach as insufficiently reliable. ${ }^{64}$ The Court concluded that the plaintiff had failed to show a reliable and administratively feasible way to identify those persons belonging to the class, and on that ground it vacated the district court's grant of certification. ${ }^{65}$

As many critics have noted, Carrera's strict ascertainability requirement threatens to scuttle consumer class actions. ${ }^{66}$ Those who buy low-priced items usually throw away their receipts; retail stores rarely keep records of purchasers, and manufacturers have no way to know who bought an item downstream. So there is likely to be no evidence to prove class membership other than the uncorroborated testimony of the buyers themselves.

To be sure, not all courts have embraced strict ascertainability. The

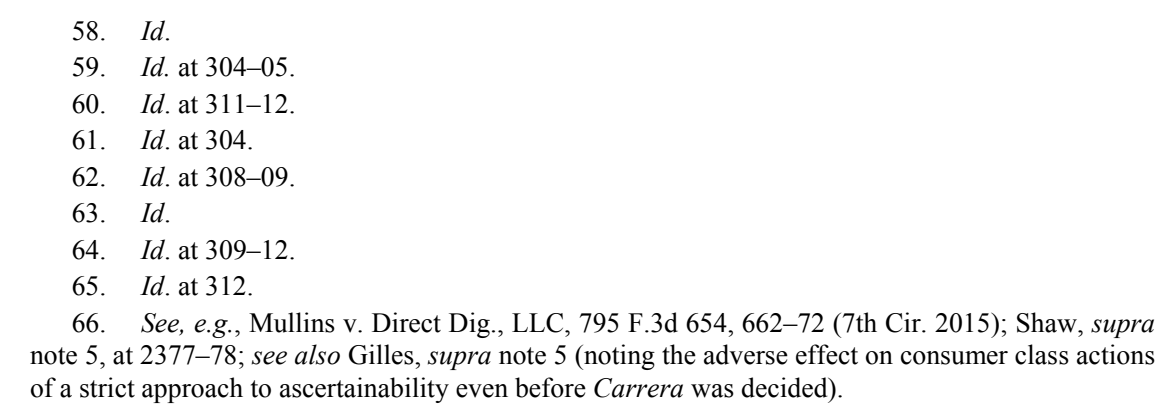


Third Circuit has endorsed $i^{67}$ with the Eleventh Circuit indicating support ${ }^{68}$ and quite a few lower courts following suit. ${ }^{69}$ However, the Seventh Circuit rejected it in a strongly worded and carefully reasoned opinion, ${ }^{70}$ and the Sixth and Ninth Circuits have followed the Seventh Circuit's lead, ${ }^{71}$ as have a number of lower courts. ${ }^{72}$ Many federal courts of appeal have not yet taken a position on the issue, and it is too early to tell how the circuit conflict will finally be resolved. ${ }^{73}$

67. See Carrera, 727 F.3d at 306; Byrd v. Aaron's Inc., 784 F.3d 154, 163-65 (3d Cir. 2015); Grandalski v. Quest Diagnostics Inc., 767 F.3d 175, 185 (3d Cir. 2014); Hayes v. Wal-Mart Stores, Inc., 725 F.3d 349, 354-56 (3d Cir. 2013); Marcus v. BMW of N. Am., LLC, 687 F.3d 583, 592-94 (3d Cir. 2012). But see Shelton v. Bledsoe, 775 F.3d 554, 560-63 (3d Cir. 2015) (holding that strict ascertainability does not apply to 23(b)(2) class actions exclusively seeking injunctive or declaratory relief). However, there has been some resistance from district courts in the Third Circuit. See, e.g., City Select Auto Sales, Inc. v. BMW Bank of N. Am. Inc., No. 13-4595, 2015 WL 5769951, at *8-9 (D.N.J. Sept. 29, 2015) (following binding Third Circuit precedent to reject certification, but noting that a defendant's "lack of records and business practices makes it more difficult for a plaintiff to ascertain the members of an otherwise objectively verifiable low-value class, which may cause class members to suffer" and that "[s]everal courts have criticized the Third Circuit as imposing too high of a burden on plaintiffs") (citations omitted). Some read Byrd, supra, as a modest retreat from Carrera's strict ascertainability requirement. But I do not read the case that way. Byrd clarifies strict ascertainability and distinguishes it from other Rule 23 requirements, but it does not retreat from a strict standard. See Byrd, 784 F.3d, supra, at 163 (affirming the strict ascertainability requirement). To be sure, the court makes clear that a plaintiff need not necessarily "be able to identify all class members at class certification," just show that they can be identified in a reliable and administratively feasible way. Id. However, as the court notes, this was already clear from Carrera. Id.

68. See Karhu v. Vital Pharms., Inc., 621 Fed. Appx. 945, 947-48 (11th Cir. 2015).

69. Hughes v. Ester C Co., 317 F.R.D. 333, 348-49 (E.D.N.Y. 2016) (noting that Second Circuit district courts have "reached contrary results" on ascertainability and denying that there is a trend in the Second Circuit toward rejecting strict ascertainability) (citations omitted); Xavier v. Philip Morris USA Inc., 787 F. Supp. 2d 1075, 1089-90 (N.D. Cal. 2011); Weiner v. Snapple Beverage Corp., No. 07 CIV 8742, 2010 WL 3119452, at*12-13 (S.D.N.Y. Aug. 5, 2010) (finding a class not ascertainable when the putative class consisted of purchasers of Snapple beverages). See generally Gilles, supra note 5, at 310-12 (collecting earlier cases).

70. Mullins, 795 F.3d at 659-72 (7th Cir. 2015).

71. Briseno v. ConAgra Foods, Inc., 844 F.3d 1121, 1126-32 (9th Cir. 2017); Rikos v. Procter \& Gamble Co., 799 F.3d 497, 525-26 (6th Cir. 2015).

72. See, e.g., In re Dial Complete Mktg. \& Sales Practices Litig., 312 F.R.D. 36, 48-52 (D.N.H. 2015) (quoting Mullins extensively while rejecting Carrera and finding ascertainability satisfied despite lack of proof-of-purchase within consumer class); Belfiore v. Procter \& Gamble Co., 311 F.R.D. 29, 65-67 (E.D.N.Y. 2015) (noting conflict between Mullins and Byrd and deciding that "[b]ecause it is unlikely that consumers will retain receipts for low cost items such as wipes, plaintiff may rely on affidavits for those without receipt .... To require receipts would render class actions against producers almost impossible to bring.") (internal quotations omitted) (citation omitted); Goldemberg v. Johnson \& Johnson Consumer Co., 317 F.R.D. 374, 398 (S.D.N.Y. 2016) (noting the conflict between Carrera and Mullins and rejecting strict ascertainability because "denial of class certification in consumer protection cases like these on the basis of ascertainability would severely contract the class action mechanism as a means for injured consumers to seek redress under statutes specifically designed to protect their interests.") (citation omitted).

73. See, e.g., Sandusky Wellness Ctr., LLC v. Medtox Scientific, Inc., 821 F.3d 992, 995-96 (8th Cir. 2016) (noting that a class "must be adequately defined and clearly ascertainable" and that 
Notably, the major treatises on federal procedure do not stake out a clear position in this debate. They tend to mush the different approaches together as if they were all just slight variations on the same ascertainability theme. ${ }^{74}$ This is a bit surprising, but maybe not totally inexplicable. Strict ascertainability has intuitive appeal that can make it appear to be a sensible extension of the ascertainability requirement. At first glance, it might seem quite reasonable that the defendant, the court, and the class attorney should all be able to tell at some point in the litigation who it is that is actually alleging the rights violation and pressing a claim for relief. After all, it is not customary for courts to adjudicate lawsuits brought by persons whose identities are not even reasonably knowable. As we shall see, this is one of the core concerns that supporters of weak ascertainability must address.

\section{B. A Critical Look at the Policy Reasons for Strict Ascertainability}

It is quite remarkable that ascertainability has become so prominent, especially since Rule 23 does not even mention it. Some courts locate the requirement in Rule 23 's prefatory clause, ${ }^{75}$ which they interpret to require the existence of a "class" as a pre-condition to applying Rule 23's express provisions. ${ }^{76}$ Whatever the merits of this interpretation, it does not support strict ascertainability. A class can exist without anyone knowing precisely who is and who is not a member. ${ }^{77}$

the Eighth Circuit had not yet "outlined a requirement of ascertainability," and seeing no need to choose between the prevailing views) (citation omitted).

74. See, e.g., NEWBERG ON Class ACtions, supra note 48, § 3:3 (noting different views but collapsing them all into a single ascertainability requirement without clearly marking the distinctions); 7A WRIGHT ET AL., supra note 27, 1760 (noting differences as if they were slight variations on a single ascertainability requirement). But see 5 MOORE'S FEDERAL PRACTICE, supra note $43, \S 23.21[3][\mathrm{a}]$ (clearly marking the difference between strict and weak ascertainability, yet still presenting the distinction as just two ways to apply ascertainability without evaluating the merits of each approach or exploring the policy implications).

75. FED. R. CIV. P. 23(a) (stating that "one or more members of a class may sue ... as representative parties" if certain conditions are satisfied).

76. See NeWBerg On Class Actions, supra note 48, $\S 3: 2$. They hold that a class exists only if it has a clear, definite, and objective definition. Id. But see Briseno, 844 F.3d at 1124-26 (9th Cir. 2017) (concluding that a sensible construction of Rule 23 does not imply an "administrative feasibility" requirement, i.e., strict ascertainability).

77. Rule 23(c)(1)(B) requires that a judge certifying a class action define the class and the class claims, issues, or defenses in her certification order. FED. R. CIV. P. 23(c)(1)(B). But it says nothing about being able to identify individual class members, and few courts applying strict ascertainability rely on 23(c)(1)(B). See, e.g., Byrd v. Aaron's Inc., 784 F.3d 154, 163 (3d Cir. 2015) (holding that strict ascertainability is distinct from 23(c)(1)(B)); NEWBERG ON CLASS ACTIONS, supra note 48, $33: 2$ (noting that only a "minority" of courts rely on 23(c)(1)(B)). This is sensible. Subsection (c)(1)(B) was added to Rule 23 in the 2003 rule amendments and the advisory committee note says nothing about the provision. FED. R. CIV. P. 23(c)(1)(B) advisory committee's note. Given this silence, it seems likely that the committee did not mean to make any change in 
Courts sometimes argue that the inherent character of a class action or the intrinsic nature of a class requires strict ascertainability. ${ }^{78}$ But formalistic arguments of this sort never work. There is nothing intrinsic to a class or essential to a class action that demands ascertainability. Insofar as a class is a litigating group, it is quite sensible to treat the identities of individual members as subsumed in the identity of the group and thus irrelevant to class certification - unless identification of class members is needed for functional reasons. Indeed, if strict ascertainability inhered in the nature of a class action or the idea of a class, one would expect it to apply to all class actions. Yet even the Third Circuit, the strongest proponent of a strict ascertainability rule, declines to apply it to class actions certified under Rule 23(b)(2). ${ }^{79}$

Not surprisingly, then, policy arguments rather than formalisms are central to the case for adding strict ascertainability to Rule 23, and the debate is mostly framed in policy terms. Supporters insist that strict ascertainability is necessary so that class members can receive adequate notice, later courts can determine the preclusive effect of a class judgment, a class action can be managed efficiently, class recovery can be distributed to the class, and the defendant can have a fair opportunity to present its defenses and contest class membership. ${ }^{80}$ The following discussion examines each of these points in turn. It relies to a considerable extent on

existing class definition law, which at the time required only weak ascertainability.

78. E.g., Byrd, 784 F.3d at 162-65 (noting that "[t]he source of, or basis for, the ascertainability requirement as to a Rule 23(b)(3) class is grounded in the nature of the class-action device itself," but also discussing policy reasons for the rule). I shall argue that the policy justifications do not do the primary normative work. Instead, they serve simply as examples of why a class action without ascertainability is not a legitimate device.

79. Shelton v. Bledsoe, 775 F.3d 554, 559-63 (3d Cir. 2015). See infra notes 206-212 and accompanying text.

80. See, e.g., Shaw, supra note 5, at 2366 (noting that "the most common arguments for the ascertainability requirement" are the notice-and-opt-out argument, the distribution argument, and the preclusion argument). The Third Circuit in Carrera relies on opt out, manageability and efficiency, and the defendant's supposed due process right to test class membership. Carrera v. Bayer Corp., 727 F.3d 300, 307 (3d Cir. 2013) (noting that strict ascertainability allows "potential class members to identify themselves for purposes of opting out of a class," "ensures that the parties can identify class members in a manner consistent with the efficiencies of a class action," and "provides due process by requiring that a defendant be able to test the reliability of the evidence submitted to prove class membership"); see also Byrd, 784 F.3d at 162 n.5 (3d Cir. 2015) (summarizing the policy arguments in Marcus v. BMW and Carrera v. Bayer Corp.). In criticizing the strict ascertainability requirement, the Seventh Circuit targets four policy arguments that proponents advance: (1) that it promotes administrative convenience (essentially the manageability and efficiency argument), (2) that it ensures fairness to absent class members by facilitating individual notice for opt out, (3) that it avoids the unfairness to injured class members of distributing recovery to uninjured parties, and (4) that it protects the due process interests of the defendant and facilitates the defendant's use of preclusion in a later suit. Mullins v. Direct Dig., LLC, 795 F.3d 654, 663-72 (7th Cir. 2015); see also Briseno, 844 F.3d at 1127-32. 
work by others criticizing these arguments on functional grounds, including an excellent student Note on the subject. ${ }^{81}$ In each case, it also makes the link to legitimacy explicit. This then sets the stage for the discussion in Part $\mathrm{IV}$, which focuses on the quite different legitimacy-based arguments for strict ascertainability.

\section{Notice and Opt-Out}

One common argument for strict ascertainability is that it is needed to provide the notice that Rule 23(b)(3) requires. ${ }^{82}$ Rule 23 provides that "the court must direct to class members the best notice that is practicable under the circumstances, including individual notice to all members who can be identified through reasonable effort." ${ }^{\text {} 83}$ The purpose of this notice requirement is to inform class members of their right to opt out or "enter an appearance through an attorney., ${ }^{, 4}$

This notice argument does not work. One can concede the need for (b)(3) notice and still reject strict ascertainability. There is no Rule 23 or due process requirement that notice actually reach each and every class member or even that it be personally directed toward each individually. ${ }^{85}$ Rule 23 requires only that individual notice be given to "members who can be identified through reasonable effort." ${ }^{, 86}$ As some have argued, the linking of individual notice to reasonable identifiability assumes that there will sometimes be class members who cannot be identified. ${ }^{87}$ And those who are not identifiable can still receive notice through print media, television, the Internet, and other forms of publication. ${ }^{88}$

81. The student Note is: Shaw, supra note 5. Moreover, the Seventh Circuit in Mullins, supra note 80 , and the Ninth Circuit in Briseno, supra note 80, both review the functional arguments with some care. My discussion repeats many of the same points, but it also refines the analysis in some respects.

82. See, e.g., Carrera, 727 F.3d at 305-06; Shaw, supra note 5, at 2367-69 (criticizing the notice argument).

83. FED. R. CIV. P. 23(c)(2)(B).

84. See FeD. R. CIV. P. 23(b)(2)(B)(v) (recognizing an opt-out right); FED. R. CIV. P. 23(b)(2)(B)(iv) (recognizing a right to appear).

85. See Juris v. Inamed Corp., 685 F.3d 1294, 1321 (11th Cir. 2012); Mirfasihi v. Fleet Mortg. Corp., 356 F.3d 781, 786 (7th Cir. 2004); MOORE's FEDERAL PRACTICE, supra note 43, § 23.102[2] (noting that notice need not be actually received). See generally Mullane v. Cent. Hanover Bank \& Trust Co., 339 U.S. 306, 313-15 (1950) (holding that the due process requirements for notice depend on a balance of individual and government interests).

86. FED. R. CIV. P. 23(c)(2)(B).

87. Mullins v. Direct Dig., LLC, 795 F.3d 654, 665 (7th Cir. 2015); Shaw, supra note 5, at 2367-69.

88. See Mirfasihi, 356 F.3d at 786. And to give this publication notice, all one needs is the kind of clear class definition that weak ascertainability guarantees. 
Also, there is no strong policy reason to provide individual notice to members of a small-claim class. Class members have too little at stake to make individual litigation cost-justified and therefore have no reason to opt out or intervene. The empirical evidence confirms this point. The opt-out rate in small-claim class actions is vanishingly small, and absent class members virtually never intervene. ${ }^{89}$ Under these circumstances, strict ascertainability creates a Catch-22. It guarantees individual notice by making it impossible for class members to sue, and thus assures notice will never be given because no lawsuit will ever be brought. ${ }^{90}$

Still, there is something odd about a court adjudicating a class action when there is a good chance that no absent class members can be clearly identified. What makes this odd, however, is not the inability to give notice. The notice difficulty is symptomatic of a deeper problem. That problem has to do with the impossibility of individuating class members with individual damages claims. When class members are anonymous, neither the named plaintiff nor the class attorney can attend to their individual interests. It is true that the class attorney represents the class as a whole. ${ }^{91}$ But it is still troubling that she has no way to take account of possibly divergent class member interests on an individual basis when evaluating the interests of the class. Anonymity also limits the relationship between the judge and individual claimants. When the judge has no way to individuate class members, she has no way to treat class members as individuals with distinct rights claims. But all of these concerns sound in legitimacy, not functional efficacy. The inability to give individual notice is just a symptom of the anonymity baked into the class. I explore these points further in Part IV.

89. See Myriam Gilles \& Gary B. Friedman, Exploding the Class Action Agency Costs Myth: The Social Utility of Entrepreneurial Lawyers, 155 U. PA. L. REV. 103, 133 (2006) (reporting that two studies show less than a $1 \%$ opt out rate).

90. Briseno v. ConAgra Foods, Inc., 844 F.3d 1121, 1129 (9th Cir. 2017) ("Practically speaking, a separate administrative feasibility requirement would protect a purely theoretical interest of absent class members at the expense of any possible recovery for all class members - in precisely those cases that depend most on the class mechanism."). There is also no need for the notice requirement to do substantial work in every (b)(3) class action for it to make sense as part of Rule 23. There are (b)(3) suits where it is possible to identify absent class members relatively easily, including large claim class actions for personal injury and small-claim class actions where class members can be identified from the defendant's records.

91. MOORE'S FEDERAL PRACTICE, supra note 43, § 23.120[2][c][i] (“[A]n attorney appointed class counsel must represent the interests of the class as a whole rather than the interests of individual class members.”). 


\section{Preclusion}

Another common policy argument is that strict ascertainability is needed to assure that a later court can readily give preclusive effect to a class judgment. ${ }^{92}$ To see this point clearly, suppose that a class is certified, the class action settles, and the court approves the settlement. A plaintiff, unhappy with the settlement, files a subsequent lawsuit against the same defendant on the same claim. The defendant argues that the plaintiff was a member of the earlier class and thus is precluded by the class settlement. To decide the preclusion issue, the court must determine whether the plaintiff was in fact a class member, and strict ascertainability makes this easy to do by assuring that class members can be readily identified.

The defect in this argument is that strict ascertainability is not necessary for this purpose. ${ }^{93}$ Weak ascertainability works perfectly well. The reason is simple. The class-action court does not predetermine the preclusive effect of its judgment; the judge in the subsequent suit raising a preclusion issue makes that determination. ${ }^{94}$ This later judge does not have to identify all class members to perform this task. She need only determine whether the plaintiff in the second suit was a member of the previous class, and all she needs to do that is a clear class definition. Indeed, the plaintiff in the subsequent suit will often allege enough to self-identify as a class member. And even if class membership is not evident from the complaint, simple discovery will likely reveal the truth and support a summary judgment motion.

For example, suppose the Carrera class action had been certified and the district judge had approved a settlement. Suppose that, after final judgment, a WeightSmart customer, unhappy with the settlement, decided to file a separate suit alleging a claim based on the same events. That consumer would have to plead that she purchased WeightSmart during the period that the ads were circulating, and this allegation would place her in the Carrera class as long as the purchase was made in Florida. ${ }^{95}$

92. See Carrera v. Bayer Corp., 727 F.3d 300, 306 (3d Cir. 2013); Shaw, supra note 5, at 2374 (noting the argument before criticizing it).

93. See Shaw, supra note 5, at 2374-78.

94. 7AA WRIGHT ET AL., supra note 27, § 1789.

95. Carrera, 727 F.3d at 304; see also Briseno, 844 F.3d at $1130 \mathrm{n} .9$ (discussing a similar hypothetical). The state in which the purchase was made might be clear from the complaint or inferable from the plaintiff's state of residence at the time of the purchase. It is possible that someone else might file a second class action overlapping with the first. But the second court should be able to identify the overlap, assuming the class definitions in the first and second suits are clear and definite enough. Having identified the overlap, the second court can force the attorney to redefine the class to exclude the precluded class members. 
In fact, class members in small-claim class actions have too little at stake to file separate suits. ${ }^{96}$ This is, after all, why a class action is necessary. To be sure, a consumer class action based on a big-ticket item, such as a luxury car or boat purchase, might include some class members with large enough stakes. But sellers are more likely to keep records in such cases, especially when, as seems likely for high-priced items, consumers rely on financing.

All of this is so obvious that it is surprising proponents of strict ascertainability make this argument. However, the argument has more force when it shifts from the practical difficulties of applying preclusion doctrine to the class-action court's inability to identify those whose rights it is judging (and who will as a result be precluded by its judgment). From this perspective, what matters is that the class-action court rendering the judgment have at least some way to know the individual rightholders who will be affected by its actions. In sum, the focus of concern is the anonymity of class members, just as it was for notice.

\section{Ensuring Manageability and Securing Efficiency Benefits}

Proponents of strict ascertainability sometimes point to the way the rule facilitates judicial management of class actions. ${ }^{97}$ Without strict ascertainability, they argue, a court would have to do more work at the certification and supervision stages, which would undermine the efficiency benefits that justify (b)(3) certification. ${ }^{98}$ The problem with this argument is that it does not justify strict ascertainability as a separate, mandatory Rule 23 requirement. To manage a class action effectively, a judge must know the nature of the class claims and the common questions, as well as the facts of the dispute. She need not know the identities of individual class members.

For example, a judge is perfectly capable of evaluating the (b)(3) predominance requirement as long as she is familiar with the class claims, common issues, and general facts. A judge does not actually decide any individual questions when determining predominance; she merely determines whether individual questions exist and how important they are relative to the common questions. And she can do that without knowing

96. Not all small-claim class actions necessarily fit this profile. In securities fraud class actions, large institutional investors have enough at stake to litigate separately. However, strict ascertainability normally presents no problem in those cases because courts can usually identify class members from the defendant's records.

97. See, e.g., Marcus v. BMW of N. Am., LLC, 687 F.3d 583, 593 (3d Cir. 2012); Carrera, 727 F.3d at 307.

98. Carrera, 727 F.3d at 307. 
anything about individual cases. ${ }^{99}$ Similarly, in evaluating adequacy of representation for purposes of 23(a)(4), the judge does not ask whether particular individuals in the class are adequately represented; rather, she asks whether the attorney and named plaintiffs will adequately represent the class as a whole. ${ }^{100}$

Even if strict ascertainability did help with class action management, this fact alone would not support adopting the requirement. Rule 23 treats manageability as just one factor in a (b)(3) superiority determination. ${ }^{101}$ While management difficulties increase the costs of class treatment, those costs must be balanced against the benefits of a class action. The problem with strict ascertainability is that it creates an absolute bar to certification regardless of the social benefits that a class action might generate. ${ }^{102}$

There is one class management issue that deserves special attention. Class actions, and especially small-claim class actions, are rife with agency problems. The class attorney often litigates without much, if any, oversight from class members, and this makes it possible for the attorney to settle with the defendant for a large fee and a small payout to the class. ${ }^{103}$ Rule 23 relies mainly on the judge to control these agency costs. For example, the judge chooses the class attorney; reviews a class settlement to check that it is fair, adequate, and reasonable; and also determines the amount of the class attorney's fee. ${ }^{104}$

The question then is whether strict ascertainability helps to reduce the risk of agency problems. It is difficult to see how it could. A judge does not need to know the identities of class members to choose a loyal class attorney, evaluate a class settlement, determine the fee award, or perform any of the other management tasks that reduce agency costs. Still, strict

99. Consider a consumer fraud claim. A judge does not have to know the identity of any class member to determine whether reliance is an individual question. All she has to know is the nature of the claim being asserted and sufficient facts to decide whether the defendant made uniform statements or instead customized its statements to individual consumers.

100. It is also worth noting that the Third Circuit's strict ascertainability rule requires only that the plaintiff show that class members can be identified, not that the plaintiff actually identify them at the certification stage. Byrd v. Aaron's Inc., 784 F.3d 154, 163 (3d Cir. 2015) (concluding strict ascertainability "does not mean that a plaintiff must be able to identify all class members at class certification" but only that they can be identified). This somewhat weakens any argument that identifying class members is important for evaluating certification requirements.

101. FED. R. CIV. P. 23(b)(3)(D).

102. See Mullins v. Direct Dig., LLC, 795 F.3d 654, 663-64 (7th Cir. 2015) (criticizing the administrative convenience argument on this ground); Briseno v. ConAgra Foods, Inc., 844 F.3d 1121, 1127-28 (9th Cir. 2017) (rejecting a "freestanding administrative feasibility requirement" as a condition to certification and supporting a case-specific manageability inquiry taking account of Rule 23 policies).

103. See, e.g., Macey \& Miller, supra note 39, at 19-25.

104. FED. R. CIV. P. 23(e), (g), (h). 
ascertainability might help in a different way if for some reason agency problems were more serious for class actions with mostly unidentifiable members. It is possible, for example, that an attorney would be more willing to sell out a class with anonymous members than a class whose members the attorney knows or could imagine knowing. However, this possibility depends on questionable assumptions about attorney psychology, and these assumptions need to be empirically verified. In fact, it seems likely that any psychological effect of this sort would depend on the individual amounts at stake. When class members have very little at stake, as in small-claim class actions, they have little reason to care about the lawsuit, and if they do not care, it is unlikely that the class attorney will care much about their interests even if he knows who they are.

Indeed, many view the class attorney in a small-claim class action as a private attorney general representing the public interest in effective deterrence rather than the interests of individual class members in compensation. ${ }^{105}$ On this view, agency problems manifest when the attorney agrees to a settlement that fails to meet the substantive law's deterrence goals. But there is no reason to believe that an attorney's incentives to promote the public interest depend on the identifiability of class members. Even a perfectly loyal private attorney general has no particular reason to care about the class except to the extent that class recovery promotes deterrence.

As with the notice and preclusion arguments, it is possible to recast this argument in legitimacy terms. If one believed that class actions without identifiable class members were not proper litigating units, it would not be surprising for one also to believe that such a problematic litigating entity would be difficult to manage and require creative approaches at odds with traditional methods. Thus, a concern about manageability might be linked to a deeper concern about legitimacy. And the legitimacy concern is more difficult to dismiss.

\section{Distributing Class Recovery}

A common argument for strict ascertainability focuses on the distribution of class recovery. ${ }^{106}$ In small-claim class actions that settle, notice is sent to class members inviting them to file claims to the settlement

105. See, e.g., Gilles \& Friedman, supra note 89, at 131-39; Brian T. Fitzpatrick, Do Class Action Lawyers Make Too Little?, 158 U. PA. L. REV. 2043, 2069-70 (2010).

106. See, e.g., Shaw, supra note 5, at 2369-74. The distribution argument for strict ascertainability is often treated as part of class action management-difficulties identifying class members make it more difficult for a judge to manage the remedy stage. 
fund. ${ }^{107}$ If it is important that the funds be distributed only to claimants who are in fact class members, a court must be able to determine with confidence whether a claimant is a member of the class.

This distributional argument works only if one accepts its premise, that all class recovery must be distributed to class members and only to class members. This rules out alternative methods of distribution, such as cy pres. $^{108}$ But ruling out cy pres at the outset begs the question whether cy pres is an appropriate method of distribution.

Moreover, strict ascertainability solves the distribution problem in a particularly draconian way. When courts reject class member affidavits as unreliable, they scuttle any hope of class certification, and thus assure there is no settlement to distribute, leaving class members with nothing at all. ${ }^{109}$

From a functional perspective, there are alternatives that serve the purposes of the small-claim class action much better. Cy pres, for example, solves the distribution problem by directing any left-over funds to a charity. ${ }^{110}$ In addition, there is no reason to reject class member affidavits on the ground that effective distribution requires strict standards of reliability. Given that a class member's testimony of injury and causation could support an award of damages in an individual suit, it is not at all obvious why a stricter rule should apply to class actions. ${ }^{111}$

107. Only a small fraction of the class usually files, leaving a large chunk of the fund undistributed. See, e.g., Christopher R. Leslie, The Significance of Silence: Collective Action Problems and Class Action Settlements, 59 FLA. L. REV. 71, 119-20 (2007).

108. See infra Part III.

109. See, e.g., Mullins v. Direct Dig., LLC, 795 F.3d 654, 668 (7th Cir. 2015); In re Dial Complete Mktg. \& Sales Practices Litig., 312 F.R.D. 36, 48-52 (D.N.H. 2015). There is another version of the distributional argument. According to this version, distributing recovery to anyone who files an affidavit supporting her entitlement invites frivolous filings, and paying frivolous claimants dilutes the recovery available for deserving class members. There are many flaws with this argument. See Mullins, 795 F.3d at 666-69. As a practical matter, frivolous filings would seem very unlikely in small-claim class actions, when the filer stands to receive little for her trouble. Furthermore, because few legitimate class members actually file claims on the fund, it is highly unlikely that anyone's recovery would be diluted; there should be ample proceeds to pay all claimants. Finally, frivolous claims are not unique to the class action; they are a problem in individual litigation as well. Courts have a number of tools to deal with the problem. These tools are not perfect, of course, but it makes no sense to impose a stringent requirement just in the class setting, especially when that requirement scuttles certification and, with it, any hope of relief for deserving class members.

110. See Briseno v. ConAgra Foods, Inc., 844 F.3d 1121, 1129 (9th Cir. 2017) ("The notion that an inability to identify all class members precludes class certification cannot be reconciled with our court's longstanding cy pres jurisprudence.").

111. See In re Nexium Antitrust Litig., 777 F.3d 9, 19-20 (1st Cir. 2015) (holding that affidavits are sufficient to distinguish injured from uninjured class members since unrebutted consumer testimony "would be sufficient to establish injury in an individual suit"); Mullins, 795 F.3d at 669 ("If not disputed, self-serving affidavits can support a defendant's motion for summary judgment, for example, and defendants surely will be entitled to a fair opportunity to challenge self- 
Not surprisingly, the principle supporting the distributional argumentthat all class recovery must be distributed only to class members who can verify membership -is sharply contested. ${ }^{112}$ This principle does not promote the functional purposes of the small-claim class action; indeed, it undermines those purposes by scuttling the only realistic hope class members have of recovering something for their legal claims. The principle can be justified, if at all, only as a matter of adjudicative legitimacy, as an argument that the class action is a legitimate form of civil adjudication only if it provides individual compensation for rights violations. I address this argument in Part IV.

\section{Fairness to the Defendant}

Some supporters defend the strict ascertainability requirement on grounds of fairness to the defendant. They argue that the defendant has a due process right to challenge the proof used to demonstrate class membership and also to contest any legal obligation to pay compensation to individual class members. ${ }^{113}$ To do this effectively, the argument goes, defendants must be able to identify class members in a reliable way, and strict ascertainability makes sure that this can be done. While this argument has some superficial appeal, it fails for a number of reasons. ${ }^{114}$

serving affidavits from plaintiffs. We are aware of only one type of case in American law where the testimony of one witness is legally insufficient to prove a fact. . . There is no good reason to extend that rule to consumer class actions."). In fact, more onerous proof requirements for class actions might violate the Rules Enabling Act by abridging class member's substantive rights. $C f$. Tyson Foods, Inc. v. Bouaphakeo, 136 S. Ct. 1036, 1046 (2016) (holding that sampling is permissible in a class action if it is permissible in an individual suit, for otherwise the class action would alter plaintiff's substantive rights in violation of the Rules Enabling Act).

112. Compare Byrd v. Aaron's Inc., 784 F.3d 154, 165 n.8 (3d Cir. 2015) (“Although we need not address the propriety of cy pres funds in this case, we do note that the risk of a cy pres fund is reduced, even if not entirely removed" by strict ascertainability) with Briseno, 844 F.3d at 1129 ("The notion that an inability to identify all class members precludes class certification cannot be reconciled with our court's longstanding cy pres jurisprudence.").

113. See, e.g., Carrera v. Bayer Corp., 727 F.3d 300, 307 (3d Cir. 2013); Forst v. Live Nation Entm't Inc., No. 14-2452, 2015 WL 858314, at *5 (D.N.J. Feb. 27, 2015). Cf. Wal-Mart Stores, Inc. v. Dukes, 564 U.S. 338, 367 (2011) (rejecting a sampling proposal as violating the Rules Enabling Act because it denies the defendant the right to litigate its defenses to individual claims: "a class cannot be certified on the premise that [the defendant] will not be entitled to litigate its statutory defenses to individual claims").

114. Proponents of the due process argument often cite cases that involve some form of statistical adjudication based on sampling. In Carrera, for example, the Third Circuit cites McLaughlin v. Am. Tobacco Co., 522 F.3d 215, 231-32 (2d Cir. 2008), which rejected a statistical method of calculating damages, and Wal-Mart Stores, 564 U.S. at 367, which rejected sampling to determine aggregate liability for backpay. Carrera, 727 F.3d at 306-07. However, these sampling cases are very different from the ascertainability cases. Since sampling works by extrapolating from the results in a sample of cases, a defendant is able to present its defenses only in the sample cases. By contrast, relying on affidavits to establish class membership does not prevent the defendant from 
First, there is no due process issue with class members self-identifying by filing their own affidavits. A defendant is perfectly free to rebut the affidavit with any admissible evidence showing that the affiant is not a member of the class or that the affidavit is defective. ${ }^{115}$ The defendant might have difficulty doing so, but that does not ordinarily create a due process problem. ${ }^{116}$ In an individual suit, a plaintiff can rely on her own testimony to prove that she purchased the product and suffered a loss, and in that case it is up to the defendant to rebut that testimony, just as it is up to the defendant to counter an affidavit of class membership. ${ }^{117}$

Second, defendant's total liability is unaffected by the identity of individual class members. Class member identity is relevant only for distribution and the defendant has no due process right to insist on any particular distribution. ${ }^{118}$ Nor does the defendant need to know the identities of class members in order to negotiate a reasonable settlement. All it needs is an estimate of class size (for example, the number of consumers who actually purchased WeightSmart in Florida), average damages per class member, and the likelihood of losing at the liability stage. ${ }^{119}$ Class member affidavits have nothing to do with any of these estimates. Affidavits enter the picture only when the settlement fund is distributed. ${ }^{120}$

Third, as a practical matter, most defendants have little incentive to contest affidavits when the stakes are small. Indeed, the due process argument is more likely a strategic ploy to scuttle class certification and avoid litigation altogether than a genuine effort to litigate individual issues. Without a class action, class members with small claims will not sue, and as result the defendant gets off scot-free. Given that the defendant has little

offering rebuttal evidence in every case. See Mullins, 795 F.3d at 669-72.

115. Briseno, 844 F.3d at 1131-32.

116. Id. at 1132 (quoting Mullins, 795 F.3d at 669) (noting "there is no due process right to 'a cost-effective procedure for challenging every individual claim to class membership"').

117. More generally, defendants can have difficulty proving that suits are frivolous, but that difficulty does not implicate due process rights.

118. Briseno, 844 F.3d at 1132.

119. This follows from the standard model of settlement bargaining. See generally RoBERT G. Bone, Civil Procedure: The Economics of Civil Procedure (2003) [hereinafter Bone, ECONOMICS OF PROCEDURE].

120. There is an exception. The method of distribution can affect the defendant when a class action settlement includes a reversion clause that returns any unclaimed settlement funds to the defendant. But reversion clauses make little sense as a policy matter and are generally frowned upon. See, e.g., Bailes v. Lineage Logistics, LLC, No. 15-CV-02457-DDC-TJJ, 2016 WL 4415356, at *7 (D. Kan. Aug. 19, 2016) (noting that reversion is the least desirable way to dispose of excess settlement funds); Barbara J. Rothstein \& Thomas E. Willging, Managing Class Action LitigAtion: A POCKET Guide FOR Judges 20 (Federal Judicial Center, 3d ed. 2010) (noting that "[a] reversion clause creates perverse incentives for a defendant to impose restrictive eligibility conditions and for class counsel and defendants to agree to an inflated settlement amount as a basis for attorney fees" and recommending alternatives for distributing left-over proceeds). 
incentive to contest affidavits at the distribution stage, there is no reason to preserve the option by insisting on strict ascertainability at the certification stage.

Nor is strict ascertainability necessary to assure that the defendant can assert its substantive defenses to individual claims. Whether the defendant has individual defenses is a function of the substantive law and can ordinarily be determined without identifying class members. ${ }^{121}$ To be sure, a defendant must know the facts of an individual case to mount a case-specific defense. But it is unusual for case-specific defenses to be adjudicated in a class action; normally they are left to individual litigation. ${ }^{122}$ Indeed, if case-specific defenses raise too many individual issues, the judge will conclude that common questions do not predominate and deny certification. $^{123}$

Thus, the due process argument for strict ascertainability fails. Yet there is something odd about a party being forced to defend against claims without any reasonable way to know who it is that is doing the forcing. ${ }^{124}$ It seems only fair that a defendant should be able to know the identity of the party bringing suit against it. Normally plaintiffs cannot proceed anonymously unless they have a very strong reason to do so. ${ }^{125}$ However, concerns of this sort sound in legitimacy, not functional efficacy or due-process-based fairness.

121. Sometimes what would be an individual defense in an individual suit can be handled on an aggregative basis in a class action. For example, if the defendant raises a statute-of-limitations defense, the class definition can be narrowed temporally to exclude class members who fall outside the statute-of-limitations window.

122. See 7AA WRIGHT ET AL., supra note 27, § 1790, at 585-609.

123. A result that only benefits the defendant when claims are too small to justify individual suits. One might argue that strict ascertainability reduces the risk of frivolous class actions and thus relieves the pressure they exert on defendants to settle. But this solution is overkill; it solves the problem by getting rid of consumer class actions entirely. It is rather like addressing a problem of high litigation costs by getting rid of the court system. It will work, but only by throwing the baby out with the bathwater.

124. In a small-claim class action, the real "plaintiff" is the class attorney, not the class representatives or class members. See Macey \& Miller, supra note 39, at 5-6. But recognizing the attorney as the actual opponent strains conventional assumptions about civil adjudication.

125. See, e.g., Doe v. Pub. Citizen, 749 F.3d 246, 273-74 (4th Cir. 2014) (noting that "[p]seudonymous litigation undermines the public's right of access to judicial proceedings" and holding that "a district court has an independent obligation to ensure that extraordinary circumstances support such a request [for proceeding pseudonymously] by balancing the party's stated interest in anonymity against the public's interest in openness and any prejudice that anonymity would pose to the opposing party"); 5A WRIGHT ET AL., supra note 27 , § 1321, at 382-83 ("[B]ecause of the presumption of openness with regard to American judicial proceedings, federal courts generally have been rather rigorous in not allowing the plaintiff to commence an action anonymously."); see also William S. Kleinman, Note, Who is Suing You?: John Doe Plaintiffs in the Federal Courts, 61 TEX. L. REV. 547, 547 (1982) (noting that at common law a defendant had the right to know his accuser and discussing the limited exceptions to this rule). 


\section{CY PRES}

The previous discussion explained why notice, preclusion, manageability, distributional efficacy, and defendant-focused fairness all fail as functional arguments for strict ascertainability. As we saw, the distributional argument in particular depends to a large extent on the availability of cy pres. If cy pres is impermissible or severely limited and if class recovery must go to class members, then the case for strict ascertainability is much stronger. This is what ties strict ascertainability to cy pres. The former makes at least some functional sense only if the latter is not an option. Thus, it is important to examine cy pres with care.

The following discussion analyzes the functional arguments for eliminating or severely restricting cy pres. We shall see that these arguments are no more convincing than the functional arguments for strict ascertainability. Still, like the ascertainability arguments, the cy pres arguments make more sense when recast in legitimacy terms. Cy pres is troubling because it thrusts the regulatory dimension of adjudication to the forefront and elevates deterrence over meaningful compensation for rights violations.

\section{A. Background}

Cy pres is short for "cy pres comme possible," which translates from the Norman French to as "as near as possible." 126 In the class action setting, the cy pres doctrine allows a court to distribute class recovery to a charity when it is impractical or undesirable to distribute it to individual class members. The idea is to choose a charity that is likely to use the funds for projects that indirectly benefit the class. ${ }^{127}$

To illustrate, consider the facts of Lane v. Facebook, one of the more controversial cy pres cases. ${ }^{128}$ Plaintiffs sued Facebook for violations of

126. Wasserman, supra note 6 , at 114 . Courts of equity used the cy pres doctrine in cases involving testamentary charitable trusts. When the testator's chosen beneficiary failed for some reason, the court would choose an alternate charity that served the testator's charitable intent as closely as possible. Id. at 114-15. The assumption was that the testator/settlor of the trust would prefer that the trust continue through a slight change in beneficiary than that the principal revert to the residuary legatees. $I d$.

127. A close cousin of cy pres is fluid class recovery. Instead of giving the left-over funds to a charity, however, fluid class recovery applies the funds to benefit a group that overlaps as much as possible with the class. For example, left-over funds might be used to reduce the price of a service for future consumers on the assumption that a significant portion of past consumers harmed by the legal violation would use the service again. See Redish et al., supra note 8, at 661-64. Although I focus on cy pres, much of what I say applies to fluid recovery as well.

128. Lane v. Facebook, Inc., 696 F.3d 811 (9th Cir. 2012), cert. denied sub nom. Marek v. 
federal and state privacy laws in connection with its Beacon program. The Beacon program allegedly sent information about a Facebook member's purchases to her Facebook "friends" without giving the member an adequate opportunity to block the communication. ${ }^{129}$ The plaintiffs sought injunctive relief and damages on behalf of a nationwide class of more than 3.6 million Facebook users. ${ }^{130}$

Facebook settled the class action by agreeing to terminate Beacon and pay $\$ 9.5$ million in damages. ${ }^{131}$ After deducting for attorney's fees and miscellaneous expenses, about $\$ 6.5$ million remained to be distributed to the class. ${ }^{132}$ It made no sense, however, to deliver these funds to individual class members because the per-member cost of distribution exceeded the amount available to distribute. ${ }^{133}$ So the parties agreed to distribute the fund to The Digital Trust Foundation, a charitable organization created by the parties as part of their settlement. The Foundation was set up specifically to receive the settlement funds and use those funds to support programs aimed at educating Facebook users (and others) about protecting their identities and personal information online. ${ }^{134}$ A Facebook corporate official was appointed as one of the three original directors of the Foundation - and this aspect of the settlement generated considerable controversy. ${ }^{135}$

The Lane case is unusual, though not unique, in distributing nothing at all to the class and creating an entirely new organization to serve as the cy pres beneficiary. ${ }^{136}$ More commonly, courts first attempt a distribution to the class and only afterward use cy pres to dispose of left-over funds. Moreover, the cy pres distribution is usually made to an established charity rather than a newly created entity. Lane is typical, however, in one important respect: it involves distribution of a settlement fund rather than the proceeds of a litigated judgment. Virtually all of the cy pres cases involve

\footnotetext{
Lane, 134 S. Ct. 8 (2013); see, e.g., Wasserman, supra note 6, at 129-34 (treating Lane v. Facebook as an especially problematic application of cy pres).

129. Lane, 696 F.3d at 816-17.

130. Id. at $817-18$.

131. Id. at 817.

132. Id.

133. With 3.6 million Facebook users and 6.5 million dollars to distribute, each class member would receive $\$ 1.81$ and the cost of identifying class members, organizing distribution, and paying for checks and postage was likely to exceed that amount.

134. Lane, 696 F.3d at $817-18$.

135. As the Court notes, "[t]he initial three directors were Larry Magrid, a member of the federal government's Online Safety and Technology Working Group and several other online safety organizations; Chris Hoofnagle, director of the Information Privacy Programs at the Berkeley Center for Law and Technology and former director for an office of the Electronic Privacy Information Center; and most relevant here, Timothy Sparapani, Facebook's Director of Public Policy and former counsel for the American Civil Liberties Union." Id. at 817.
}

136. Wasserman, supra note 6, at 133-34. 
settlements ${ }^{137}$ — probably because most class actions settle—so the following discussion focuses on settlements as well. ${ }^{138}$

Cy pres was not terribly controversial until a few years ago. ${ }^{139}$ In 2013, Chief Justice Roberts appended a "statement" to his vote for denial of certiorari in the Lane case, noting a number of serious cy pres issues that he thought should be addressed in a more appropriate case. ${ }^{140}$ Moreover, for the past five years, lower courts have sharply disagreed about when and how the remedy should be used. ${ }^{141}$ And many courts and commentators today either reject cy pres outright or admit considerable discomfort with its use. ${ }^{142}$ Indeed, Professor Martin Redish and his co-authors have mounted a fullscale attack, ${ }^{143}$ and even those more favorably disposed to the remedy still recommend rather strict limits on its use. ${ }^{144}$

137. I know of only one case in which a judge ordered cy pres after a fully litigated judgmentSix (6) Mexican Workers v. Ariz. Citrus Growers, 904 F.2d 1301 (9th Cir. 1990), which endorsed the use of cy pres but reversed the choice of cy pres beneficiary.

138. Some judges believe they have more latitude to approve a cy pres provision in a settlement than they do to employ cy pres after a trial judgment. See, e.g., Marshall v. Nat'l Football League, 787 F.3d 502, 509 (8th Cir. 2015) (noting that "we deal not with the court's authority to distribute unclaimed funds to a third party ... but the parties' ability to decide how to best distribute funds" (emphasis in original)). But see Nachshin v. AOL, LLC, 663 F.3d 1034, 1040 (9th Cir. 2011) (holding that "[a] proposed cy pres distribution must meet these standards regardless of whether the award was fashioned by the settling parties or the trial court.").

139. Cy pres has been a feature of class actions since roughly the mid-1970s, but apparently its use has increased markedly since 2000. See Redish et al., supra note 8, at 634-38, 653 (finding, in reliance on a data set of published opinions, that "[f]rom 1974 through 2000, federal courts granted or approved cy pres awards to third-party charities in thirty class actions, or an average of approximately once per year [and] [s]ince 2001, federal courts granted or approved cy pres awards in sixty-five class actions, or an average of roughly eight per year."). Moreover, it has generated intense controversy and come in for heavy criticism since about 2010.

140. Marek v. Lane, 134 S. Ct. 8, 9 (2013) (mentioning in particular "when, if ever, [cy pres] relief should be considered" and "how to assess its fairness as a general matter").

141. Compare Lane v. Facebook, Inc., 696 F.3d 811 (9th Cir. 2012), cert. denied sub nom. Marek v. Lane, 134 S. Ct. 8 (2013); Poertner v. Gillette Co., 618 Fed. Appx. 624 (11th Cir. 2015) with Klier v. Elf Atochem N.A., Inc., 658 F.3d 468 (5th Cir. 2011); In re BankAmerica Corp. Sec. Litig., 775 F.3d 1060 (8th Cir. 2015).

142. See, e.g., Fraley v. Batman, 638 Fed. Appx. 594, 598-99 (9th Cir. 2016) (Bea, J., dissenting) (noting that "[t]he problems with the application of cy pres to class actions are legion"); Bailes v. Lineage Logistics LLC, No. 15-cv-02457-DDC-TJJ, 2016 WL 4415356 at *7 (D. Kan. Aug. 19, 2016) (describing cy pres as a close second to reversion as a "least favored" method for disposing of unclaimed settlement funds); Abraham v. WPX Prods, Inc., 317 F.R.D. 169, 244 n. 46 (D.N.M. 2016) (endorsing judicial creativity in distributing damages especially in "negative value" cases, but emphasizing that it is "loath to use" cy pres).

143. Redish et al., supra note 8, at 665-66.

144. See, e.g., NeWBerg ON Class ACtions, supra note 48, § 12:32 (noting that "perhaps more than any other distribution method except reversion, cy pres has its critics" and that even though it is "likely the most prevalent method for disposing of unclaimed funds," "there is something of a trend away from cy pres" and "appellate courts have increasingly put restrictions" on its use); Wasserman, supra note 6, at 134-62 (recommending limits on cy pres); Tidmarsh, supra note 9 , at 792 (counting as an advantage of his fee proposal that it would reduce reliance on cy pres). 
Limits on cy pres usually have to do with when cy pres can be used and which charities can be chosen as cy pres beneficiaries. One common approach requires that a court first make a reasonable effort to distribute settlement funds to class members before considering the cy pres option. Indeed, the American Law Institute, in its highly influential Principles of the Law of Aggregation, endorses a rather strict version of this approach. ${ }^{145}$ It insists that any left-over funds after a first distribution be paid to the class whenever feasible, even if those payments end up providing additional distributions to class members who have already filed claims and received their shares. ${ }^{146}$ Only if it is not feasible to distribute to the class can the court consider cy pres, and even then the court is limited in its choice of cy pres beneficiary: there must be a close nexus between the cy pres beneficiary and the interests of the class and the goals of the substantive law. ${ }^{147}$

$\mathrm{Cy}$ pres is not the only way a judge can dispose of left-over funds. However, all the other options have serious drawbacks. One possibility is to give left-over funds back to the defendant, but this approach weakens deterrence. Another possibility is to apply the funds to increase the shares of those class members who have already filed claims and received distributions (and thus have already self-identified). But that gives some class members more than they are entitled to and treats them differently from other class members. A third possibility is to escheat left-over funds to the state as abandoned property. This is an attractive option in some respects. It serves deterrence and avoids windfalls. But it confers no benefit on class members apart from the general benefits the state provides to all its citizens, and it sacrifices an opportunity to further the substantive law indirectly by supporting an entity that advances the law's substantive goals. ${ }^{148}$

When compared with the alternatives, cy pres has some attractive features. It serves deterrence better than returning funds to the defendant; it avoids windfalls to class members, and it directs left-over funds in a way

145. American LaW InStitute, Principles of the LaW OF Aggregate Litigation $\$ 3.07$ (2010) [hereinafter ALI PRINCIPLES].

146. Id. § 3.07, cmt. b.

147. Section $3.07(\mathrm{c})$ provides that "the court, when feasible, should require the parties to identify a recipient whose interests reasonably approximate those being pursued by the class." The "reasonably approximate" standard was also used in the Rule 23 conceptual proposal that the Rule 23 Subcommittee of the Advisory Committee on Civil Rules circulated in 2015. REPORT OF THE Rule 23 Subcommittee of the Advisory Committee ON Civil Rules 24 (April 2015), https://law.duke.edu/sites/default/files/centers/judicialstudies/jul2015/I._Rule_23_Subcommittee_Re port-pgs_243-297.pdf.

148. Professor Shay Lavie has proposed another alternative, which relies on a random distribution by lottery. Shay N. Lavie, Reverse Sampling: Holding Lotteries to Allocate the Proceeds of Small-Claims Class Actions, 79 GEO. WASH. L. REv. 1065, 1066-69 (2011). 
that creates some benefit to the class. Nevertheless, there are limits imposed on the use of cy pres, and those limits can generate significant social costs. For example, they can impede certification of socially valuable class actions. A judge must be confident that there is a manageable way to deal with any left-over settlement funds before she can grant certification, and cy pres offers a workable solution. It follows that the more difficult it is for a court to rely on cy pres, the more difficult it can be for a court to certify a smallclaim class. ${ }^{149}$ And the more difficult it is to certify small-claim class actions, the less likely it is that the class action device will achieve its deterrence goals.

Moreover, restrictions placed on cy pres add costs even when class actions are certified. For example, the tighter the required nexus between the cy pres beneficiary and the class, the more costly it is to search for a suitable beneficiary. Stricter requirements also give settlement objectors more to object about when challenging class settlements, and this can increase litigation costs. And strict requirements can discourage parties from including cy pres provisions in their settlements, which can lead to greater judicial involvement and more reliance on the suboptimal alternatives of reversion and escheat.

\section{B. A Critical Look at the Policy Reasons for Restricting Cy Pres}

The standard functional objections to cy pres focus on three main concerns: agency costs, risks of judicial self-dealing, and misappropriation of class member property. ${ }^{150}$

\section{Agency Costs}

One argument against cy pres is that it weakens the incentives of class attorneys to maximize benefits for the class. The idea is that a class attorney concerned only with her own fee has no reason to maximize class recovery when her fee is calculated as a percentage of the total settlement, including

149. It is usually apparent at the class certification stage that a class action will likely produce left-over funds.

150. A fourth possible objection is that it increases administrative costs, especially when judges supervise the cy pres remedy. But most class actions generate high administrative and management costs, and those costs are tolerated because of the benefits that the class action confers. It is difficult to imagine that the marginal costs of using cy pres are terribly large compared to these other costs. In any event, proponents of costly restrictions on cy pres can hardly complain about the administrative costs of an unrestricted cy pres remedy. 
the portion subject to cy pres. ${ }^{151}$ This argument has superficial appeal, but it does not survive careful examination.

First, the existence of a cy pres component, by itself, should not adversely affect the total settlement. Since the attorney's fee depends on the total amount, the class attorney has an incentive to maximize the total. In this regard, cy pres differs from coupon settlements with which it is sometimes compared. ${ }^{152}$ In a coupon settlement, the fee depends on the total market value of all the coupons regardless of the number actually redeemed. ${ }^{153}$ As a result, the class attorney receives a large fee and the defendant ends up paying a relatively small amount if, as is quite common, few class members redeem their coupons. With cy pres, however, the defendant reaps no benefit when class members fail to claim their shares; the defendant pays the full settlement amount regardless of cy pres. To be sure, there are agency problems with class actions, but it is not clear that cy pres exacerbates them.

Second, the class attorney does not benefit in any obvious way by directing proceeds to a cy pres beneficiary rather than to the class; her fee is the same in either case. ${ }^{154}$ The defendant might be willing to pay a higher

151. See, e.g., In re Baby Prods. Antitrust Litig., 708 F.3d 163, 173 (3d Cir. 2013); Jennifer Johnston, Cy Pres Comme Possible to Anything is Possible: How Cy Pres Creates Improper Incentives in Class Action Settlements, 9 J. L. ECON. \& POL'Y 277, 289-94 (2013). Professor Martin Redish and his co-authors take the agency cost argument one step further. Redish et al., supra note 8 , at $650-51$. They argue that, by weakening the incentives of class attorneys to maximize individual recovery, cy pres violates the constitutional due process rights of absent class members. $I d$. at 650 . I am not convinced. First, as I explain in the text, cy pres does not necessarily weaken class attorney incentives, since the attorney gets the same fee with or without cy pres. Second, and more important, the due process argument proves too much. Agency problems are endemic to all principal-agent relationships. So if the mere risk of an agency problem were enough to trigger a due process violation, many well-settled litigation practices would be in constitutional jeopardy. For example, there is always a risk that a class attorney will act in her own self-interest at the expense of the class she represents, but no one suggests that this risk alone makes the class action device unconstitutional as a violation of due process. Moreover, many ordinary procedures exacerbate attorney-client agency problems without triggering due process concerns. For example, broad discovery makes it easier for attorneys hired on a fee-for-services basis to pad their billable hours at the expense of their clients. Yet I am not aware of anyone who suggests that this risk alone makes broad discovery unconstitutional. In short, while it is important to address the agency cost argument as a policy matter, it is not helpful to frame it as a due process violation; doing so only exaggerates the stakes and confuses the issues.

152. See, e.g., Baby Prods. Antitrust Litig., 708 F.3d at 178; Wasserman, supra note 6, at 136 49 (analogizing to coupon settlements); Johnston, supra note 151, at 291-92 (same). It is also different from a reversionary settlement, in which the class attorney's fee is based on the entire settlement even though any unclaimed portion reverts to the defendant.

153. The Class Action Fairness Act tries to deal with this problem by requiring that class counsel's fee be based only on the amount of the coupons actually redeemed. 28 U.S.C. § 1712(a) (2012).

154. It is possible that the attorney for the class or for the defendant might seek a personal benefit from a cy pres distribution, such as supporting her alma mater or other institution in which 
fee for the class attorney's agreement to a cy pres clause if the defendant is connected with the cy pres beneficiary or stands to gain from cy pres in some other way. ${ }^{155}$ However, I am not aware of any reliable empirical evidence indicating that this is a serious problem. Moreover, even if it is serious, it can be handled fairly easily by insisting that the beneficiary have no connections with the defendant or with any of the lawyers involved in the suit. To be sure, defendants can publicize their charitable good works, but this benefit is rather attenuated and much weaker than a reduction in out-ofpocket loss.

Third, the critics assume that the primary goal of the class action is to compensate class members. This is why agency costs are evaluated against the baseline of a class attorney devoted exclusively to maximizing class recovery. However, small-claim class actions are primarily about deterrence, not compensation. ${ }^{156}$ This means that the class attorney is better viewed as an agent of the public interest, accountable to the public rather than to the class. Thus, the critical question is whether cy pres increases the risk that attorneys will "sell out" the public's interest in optimal deterrence by agreeing to settlements that deter too weakly. It is not at all clear why that would happen.

Fourth, if cy pres creates agency problems, there is an obvious solution: calculate fees as a percentage of the amount actually distributed to the class without regard to the cy pres component. ${ }^{157}$ There is a downside to this approach. It runs the risk of either discouraging small-claim class actions and thereby weakening deterrence, or encouraging distributions to alreadyclaiming class members and thereby generating windfalls.

However, there is another way to view the agency cost argument. Instead of being about class recovery, the argument might be about the adjudicative legitimacy of a form of litigation in which the attorney is center stage and the actual right holders do not count as a practical matter. In other words, the concern might be that the litigation is structured so that the attorney has no reason to regard the class or class members in a fiduciary sense. Cy pres is an obvious focal point for this concern because it highlights the problem in particularly dramatic fashion-class recovery is simply given away to a third party who has no legal rights at stake and no

\footnotetext{
she has a personal interest. See Wasserman, supra note 6, at 122-25. I do not know how often this occurs, but it can be handled in a relatively straightforward way by prohibiting the practice and enlisting the judge's help to ensure that the choice of cy pres beneficiary is not tainted in this way.

155. Id. at $120-21$.

156. See supra note 105 and accompanying text.

157. Others have included this limitation in their proposals. See Johnston, supra note 151, at 289-91; Wasserman, supra note 6, at 137-42.
} 
role in the suit. Thus, as was the case for strict ascertainability, the flawed functional argument can be modified so that it expresses a more plausible legitimacy concern.

\section{Judicial Self-Dealing}

Many critics of cy pres worry that judges will choose their favorite charities or that parties will choose charities that judges prefer in the hope of influencing judicial approval of the settlement. ${ }^{158}$ There are some notorious examples of judicial self-dealing, and they have been widely publicized and roundly condemned. ${ }^{159}$ I do not know how pervasive this practice ever was, but I suspect that judges have largely curtailed it now that it has come in for heavy criticism. ${ }^{160}$ If it is still a problem, there is a fairly simple solution: bar the judge from approving a charity with which she currently has, or once had, a significant relationship. ${ }^{161}$

The concern about judicial self-dealing sometimes takes a different form. Critics argue that cy pres should be restricted or eliminated because it produces an appearance of impropriety even if it produces few actual instances of improper conduct. ${ }^{162}$ This form of the criticism makes it too easy for the critic; it eliminates any need to produce actual evidence of selfdealing. It focuses on public perceptions and assumes that the public will think less of judges or the court system - and possibly lose faith in the judiciary. I know of no empirical evidence to support these assumptions, and I find them quite implausible. It seems far-fetched that the public will abandon faith in the judiciary just because a class action rule creates a theoretical risk of judicial self-dealing.

In fact, I suspect that frequently arguments about the appearance of impropriety are not really about appearances at all. The reason that critics believe a measure like cy pres will appear improper is because they believe

158. See Wasserman, supra note 6, at 124-25.

159. See, e.g., Editorial, When Judges Get Generous, WASH. Post, Dec. 17, 2007, at A20; Adam Liptak, Doling Out Other People's Money, N.Y. TimeS, Nov. 26, 2007, at A14; see also Adam Liptak, When Lawyers Cut Their Clients Out of the Deal, N.Y. TIMES, Aug. 13, 2012, at A12; Wasserman, supra note 6, at $125 \mathrm{n} .119$ (noting some examples). Lawyers have their favorite stories, but as with all anecdotal evidence, one must be cautious about accepting these stories at face value.

160. Charities sometimes lobby judges to be selected as cy pres beneficiaries. Johnston, supra note 151 , at 285 . This may be unseemly, but it has the advantage of expanding the set of options beyond those the lawyers suggest and making it easier for a judge to identify promising recipients. In any case, if it is a problem, it can be prohibited without doing away with cy pres.

161. This might increase the cost of identifying a suitable charity, but probably not by all that much.

162. See Wasserman, supra note 6, at 124-25. 
it is improper and attribute that belief to the rest of the public. And they believe it is improper because they think it is not a legitimate part of a properly working system of civil adjudication.

\section{Misappropriating Class Funds}

One of the common criticisms of cy pres is that it redirects funds that belong to class members. The ALI's Principles of the Law of Aggregate Litigation strongly endorses the idea that all settlement funds are the property of class members: "funds generated through the aggregate prosecution of divisible claims are presumptively the property of the class members." "163 The Rule 23 conceptual proposal circulated in 2015 endorsed the same principle, ${ }^{164}$ and many judges and commentators follow it today. ${ }^{165}$

There are several problems with the property argument. First, any notion that distributions should go to class members because the funds are their property must deal with the fact that class counsel consents to cy pres relief on behalf of the class whenever a cy pres provision is part of a settlement. Imputing consent in this way is susceptible to agency problems, to be sure, but the mere possibility of agency problems is not a good enough reason to dismiss consent out-of-hand. ${ }^{166}$ Provided that all class certification requirements are met, including adequacy of representation, the argument for consent has some force. ${ }^{167}$

Second, a class member who has a chance to file a claim to a portion of the fund and chooses not to do so can hardly complain about not receiving a distribution. If that class member ever had a property right to a proportionate share, she has waived her right by not filing a claim. To be sure, a class member must have notice of the opportunity to file a claim

163. ALI PRINCIPLES, supra note 145, at $\S 3.07 \mathrm{cmt}$. b. Accordingly, section 3.07 limits the use of cy pres to situations where class distributions are infeasible and imposes restriction on the choice of cy pres beneficiary. Id.

164. REPORT OF THE RULE 23 SubCOMmitTEe, supra note 147, at 27.

165. See, e.g., Klier v. Elf Atochem N. Am., Inc., 658 F.3d 468, 474 (5th Cir. 2011) ("The settlement-fund proceeds, having been generated by the value of the class members' claims, belong solely to the class members."); In re BankAmerica Corp. Sec. Litig., 775 F.3d 1060, 1064 (8th Cir. 2015) (agreeing with the Fifth Circuit in Klier that "settlement funds are the property of the class").

166. It is worth noting that there are also agency problems in ordinary attorney representation.

167. At least as a reason not to impose special restrictions on cy pres beyond the customary review of class settlements for fairness, reasonableness, and adequacy. In this regard, it is worth noting that although some courts review cy pres provisions simply as part of an overall settlement review under the fair, reasonable, and adequate standard- see, e.g., In re Baby Prods. Antitrust Litig., 708 F.3d 163, 172-74 (3d Cir. 2013) - most courts analyze cy pres provisions separately and apply distinct requirements to them. 
before it is fair to imply a waiver, but a broad notice campaign is likely to reach many, if not most, members of the class.

Third, and most important, this objection to cy pres assumes that undistributed funds are owned by class members. This is a highly dubious assumption. Each class member at most owns her particular share of the recovery. Because of this, there is no argument from property rights to insist on distributing left-over funds to the same class members who have already received their shares. ${ }^{168}$ One might argue that all class members own the funds in common, but I do not see any basis for imputing common ownership when each has a separate and distinct legal right to relief. Nor does it make any sense to attribute ownership to the class qua class since a class is not an entity capable of owning anything. ${ }^{169}$

Indeed, it is not even clear that class members have a property right in their individual shares. ${ }^{170}$ Whether they do depends on the best interpretation of the substantive law coupled with the small-claim class action procedure that enforces it. This is a complicated point and I will only outline the argument here. The core idea is that the substantive law and class action procedure, together, define the substantive entitlements of class members and that as a result class members have a right only to a distribution that best serves substantive and procedural goals. ${ }^{171}$ If deterrence is the primary goal, as it is for many of the statutory claims that class members assert in small-claim class actions, ${ }^{172}$ what matters most is that the defendant pay for the harm it causes, not that class members actually receive what the defendant pays. ${ }^{173}$ It follows that class members do not own shares of the recovery in a property sense; they own only what they receive from a distribution scheme that optimally serves deterrence goals. ${ }^{174}$

168. The ALI's Principles of the Law of Aggregate Litigation, for example, rely on the property principle to justify distributing left-over funds to class members who have filed claims and already received distributions. ALI PRINCIPLES, supra note 145, §3.07(b), cmt. b.

169. Professor David Shapiro has suggested that a class might be conceived as an entity for some purposes. See David L. Shapiro, Class Actions: The Class as Party and Client, 73 NOTRE DAME L. REV. 913, 918-19 (1998). But the entity view, whatever its merits in other respects, makes no sense when applied to the distribution of settlement funds.

170. One might argue that class members have a contractual right to settlement proceeds, but that right is conditional on whatever cy pres distribution the settlement agreement contemplates.

171. For example, it might be that the best interpretation of the substance-procedure package is that class members have at most a right to make claims on the recovered funds and to receive their shares if they meet the claiming requirements.

172. See supra note 105 and accompanying text.

173. Indeed, from a deterrence perspective, substantive goals might be better served by distributing the left-over funds to a third party that will use those funds to promote compliance with the substantive law.

174. If the class action is the most effective procedural vehicle for enforcing the substantive law and achieving the deterrence goal, then class member entitlements are contingent on the distribution 
There might be sound pragmatic reasons to distribute to class members whenever feasible, but that does not mean that class members "own" any portion of the recovery. To be sure, the Supreme Court has held that the claims of class members count as "property" within the meaning of the Due Process Clause. ${ }^{175}$ However, this holding does not imply that class members also have substantive property rights in the remedy. ${ }^{176}$

Not surprisingly, courts are a bit confused about all of this. For example, a court might ignore treble damages and focus only on actual loss when determining the proper distributions to class members, notwithstanding that the substantive law confers a right to treble damages. ${ }^{177}$ It is difficult to understand how a property right of the sort cy pres critics invoke could possibly stop short of including a class member's complete substantive entitlement. Moreover, many judges assume that a class member's property includes full compensation for actual loss even when a case settles for much less. ${ }^{178}$ This makes no sense. In an individual suit, a plaintiff does not have a right to full compensation when the suit settles; she has a right only to what the settlement gives her. There is no reason why it should be any different for a class action. ${ }^{179}$

Given this confusion, it is reasonable to ask whether the property argument is really what it seems to be. We assumed that the argument takes the following form: the funds belong to class members, and therefore class

scheme that facilitates effective use of the class action-and that scheme often entails a significant cy pres component.

175. See Mullane v. Cent. Hanover Bank \& Tr. Co., 339 U.S. 306, 313 (1950).

176. It is not even obvious that class members have a right to class recovery when the substantive legal right at issue is justified on grounds other than deterrence. See Redish et al., supra note 8, at 665 (arguing that left-over funds should revert to the defendant because they are the defendant's property until they are actually claimed).

177. See, e.g., In re Lupron Mktg. \& Sales Practice Litig., 677 F.3d 21, 33-35 (1st Cir. 2012) (citing the ALI Principles with approval, but holding that the "next best relief" was a cy pres distribution rather than an additional distribution to past claimants in order to satisfy their treble damages claims, because "the consumer fund was established for the benefit of all consumer purchasers of Lupron, not just the 11,000 who filed claims").

178. See In re BankAmerica Corp. Sec. Litig., 775 F.3d 1060, 1065-66 (8th Cir. 2015) (noting that for purposes of authorizing a cy pres distribution, "[i]t is not true that class members with unliquidated damage claims in the underlying litigation are 'fully compensated' by payment of the amounts allocated to their claims in the settlement"); Klier v. Elf Atochem N.A., Inc., 658 F.3d 468, 475 (5th Cir. 2011) (holding that "[b]ecause the settlement funds are the property of the class," unclaimed funds must be distributed to class members whenever feasible, "except where an additional distribution would provide a windfall to class members with liquidated-damages claims that were 100 percent satisfied by the initial distribution"); ALI PRINCIPLES, supra note $145, \S 3.07$ $\mathrm{cmt} \mathrm{b}$, at 219 (justifying further distributions to the class by noting that "few settlements award 100 percent [recovery]").

179. Even apart from the settlement, class members are entitled at most to the expected value of their claims before trial, and expected value discounts the substantive entitlement by the likelihood of success. BONE, ECONOMICS OF PROCEDURE, supra note 119. 
members (not some third party) should receive the funds. However, the argument makes more sense in reverse: class members should receive the funds, and therefore the funds belong to class members. And class members should receive the funds because that is what adjudication is supposed to do. When the argument is understood in this way, the normative work is done not by property rights, but by a theory of adjudicative legitimacy that prescribes what adjudication should and should not do.

\section{THE LEgITIMACY ARgUMENT}

No matter how strongly one supports class actions-and I count myself as a very strong supporter - one cannot deny that a small-claim class action without strict ascertainability and with cy pres is a rather odd litigation beast. The lawsuit has anonymous - in fact irrelevant - right holders and a lawyer with no reason to care about her clients; it has a defendant who is unable to identify the persons against whom it must defend and a judge who has no basis for regarding plaintiffs as individuals, and it involves relief that need not benefit right holders as long as it secures deterrence for the public at large. ${ }^{180}$ And all of this is tolerated in a case where each plaintiff has her own individual substantive right that entitles her to damages for her own personal loss.

None of these features affect the manageability or efficiency of the class action. Nor are they about whether the court can send notice to class members or determine preclusive effects in future suits. And they are certainly not about agency costs or judicial abuse. If these features are troubling, it is because they raise doubts about the legitimacy of the class action procedure that produces them. The concern is that a class action with these features does not belong in adjudication given what adjudication is supposed to do.

These legitimacy concerns crop up from time to time. In their 2010 article, Professor Martin Redish and his co-authors mount an attack on cy pres that relies in large part on Article III, Rules Enabling Act, and separation-of-powers arguments grounded in legitimacy concerns. ${ }^{181}$

180. In consumer class actions, there is no assurance that class members will make any future purchases when they believe the defendant has wronged them. So the lawsuit's deterrent effect is likely to benefit class members only indirectly as members of the public and not in any personal way.

181. Redish et al., supra note 8 , at 641-50. At its core, this legitimacy critique assumes that courts can only award damages for rights violations, and then only in favor of persons whose rights have actually been violated. Cy pres supposedly transgresses these limits by forcing defendants to pay third parties who are not adverse to them and whose rights have not been violated - thus exceeding the limits of Article III-and also by substituting what is in practical effect a "civil fine" 
Moreover, occasionally one sees glimmers of the legitimacy critique in judicial opinions. For example, some judges justify strict ascertainability and limited cy pres by linking them to Article III. ${ }^{182}$ Also, some treat ascertainability as a threshold, even axiomatic, condition that must be satisfied in addition to the functionally-oriented Rule 23 requirements, a view that points to deeper foundations for ascertainability than functional efficacy. ${ }^{183}$ Occasionally judges criticize cy pres for penalizing the defendant or promoting "social engineering," and these arguments signal a concern about the proper limits on judicial power in civil cases. ${ }^{184}$

for the compensatory regime created by the substantive law-thus violating the Rules Enabling Act and separation-of-powers principles. Id. at 641-44 (Article III); 644-50 (Rules Enabling Act and separation of powers). While I engage the legitimacy critique underlying these legal arguments in the text, I do not address the legal arguments themselves. Nevertheless, it is worth mentioning that Professor Redish and his co-authors rely on an unnecessarily crabbed interpretation of Article III and an excessively narrow, indeed formalistic, reading of the Rules Enabling Act and separation-ofpowers principles. Cy pres does not force a defendant to pay a third party who has suffered no legal injury. The defendant pays only what the substantive law says it should pay. Cy pres affects the distribution of defendant's total liability, a matter as to which the defendant has no constitutional interest. And it does so by assuring that left-over funds are distributed in a way that serves the purposes of the substantive law. To be sure, cy pres enables small-claim class actions, but smallclaim class actions aim to further the deterrence purposes of the substantive law. But see id. at $653-$ 56 (criticizing small-claim class actions as "faux class actions"). Thus, cy pres does not improperly modify the substantive law; to the contrary, it assures that the substantive law is properly enforced and its policies served. It is not at all clear why this should offend Article III, the Rules Enabling Act, or separation-of-powers principles.

182. See, e.g., Sherrod v. Enigma Software Grp. USA, LLC, Case No. 2:13-cv-36, 2016 WL 25979 , at *3 (S.D. Ohio Jan. 4, 2016) (“Ascertainability is either an 'implied requirement' of Rule 23 ... or an inherent requirement of Article III."). In addition, some judges note the availability of alternative enforcement mechanisms when dismissing on ascertainability grounds, suggesting perhaps that the alternatives are more legitimate. See, e.g., Sethavanish v. ZonePerfect Nutrition Co., Case No. 12-2907-SC, 2014 WL 580696, at*5 n.5 (N.D. Cal. Feb. 13, 2014) (mentioning attorney general actions brought on behalf of the state).

183. See 2 NeWBerg ON Class ACtions, supra note 48, 3:1 (noting that some courts treat ascertainability as "axiomatic" and "fundamental" and noting that it is linked to due process and class action legitimacy); 5 MOORE's FEDERAL PRACTICE, supra note 43, § 23.21[1] (stating that it is "axiomatic" that "a class must exist"). See also Shaw, supra note 5, at 2400-402, n.206 (noting that courts that treat ascertainability as a threshold requirement see it as "a feature of a cohesive group," but criticizing this position).

184. See, e.g., Six (6) Mexican Workers v. Ariz. Citrus Growers, 904 F.2d 1301, 1312 (9th Cir. 1990) (Fernandez, J., concurring) (objecting to judges getting involved in ordering cy pres without party agreement as "an exercise in social engineering by a judge, who ... has no legitimate plaintiff to give the money to" and "a vehicle to punish defendants in the name of social policy, without conferring any particular benefit upon any particular wronged person"). See also Mirfasihi v. Fleet Mortg. Corp., 356 F.3d 781, 784 (7th Cir. 2004) (rejecting the notion that cy pres confers an indirect benefit on the class and describing it as "purely punitive" when it focuses on disgorging defendant's unlawful gains). Also, courts sometimes worry more about using cy pres when they have to craft the remedy themselves as opposed to simply implementing a cy pres remedy crafted by the parties, a distinction that might indicate a concern about the proper limits of judicial power. See, e.g., In re Lupron Mktg. \& Sales Practice Litig., 677 F.3d 21, 38 (1st Cir. 2012) (expressing concern about parties leaving the choice of cy pres beneficiary to the discretion of the judge and noting that "[d]istribution of funds at the discretion of the court is not a traditional Article III function"). See 
The following discussion first examines the standard responses to the legitimacy critique and then searches for analogies in current litigation practice that support the legitimacy of this form of litigation. The most promising analogy, I shall argue, is to the (b)(2) class action. This section closes with a brief discussion of the analogy's implications for ascertainability and cy pres.

\section{A. Standard Arguments}

Many critics of strict ascertainability (and to a lesser extent, restricted cy pres) argue that the doctrine scuttles small-claim class actions. ${ }^{185}$ This argument, while valid, misses the point. A proponent of strict ascertainability can agree that small-claim class actions are socially valuable, yet still deny that they are appropriate for adjudication when they involve anonymous classes and attorney-driven, deterrence-focused litigation. In a system of institutional differentiation and separation of powers, there are limits to what any branch of government should do, and these limits are binding even when judicial intervention might yield socially valuable results.

Some commentators address the legitimacy critique by arguing from the dichotomy between private law and public law models of litigation. ${ }^{186}$ The private law model views the primary purpose of adjudication as resolving private, dyadic disputes by furnishing individualized, victim-focused relief. ${ }^{187}$ The public law model extends more broadly; it accepts lawsuits that vindicate public interests, involve multiple parties, and grant broad relief. ${ }^{188}$ The argument based on this dichotomy starts by linking strict

generally David Marcus, The History of the Modern Class Action, Part I: Sturm und Drang, 19531980, 90 WASH. U. L. REV. 587, 592-98 (2013) (recounting the history of the modern class action in terms of a tension between a broad "regulatory conception" and a narrower "adjectival conception" that fit the class action into conventional litigation and eschewed broad regulatory objectives for it).

185. See, e.g., Mullins v. Direct Dig., LLC, 795 F.3d 654, 658 (7th Cir. 2015); Briseno v. ConAgra Foods, Inc., 844 F.3d 1121, 1129 (9th Cir. 2017); Gilles, supra note 5, at 307; Shaw, supra note 5 , at 2378 .

186. See, e.g., Gilles, supra note 5, at 309-10, 323. Professor Abram Chayes set out these two models of litigation in a now-famous article published in 1976. Abram Chayes, The Role of the Judge in Public Law Litigation, 89 HARV. L. REV. 1281, 1282-84 (1976). Other scholars have framed similar dichotomies using different labels. See Meir Dan-Cohen, Bureaucratic Organizations and the Theory of Adjudication, 85 COLuM. L. REV. 1, 1-7 (1985) (highlighting differences between the "arbitration model" and the "regulation model"); Owen M. Fiss, The Social and Political Foundations of Adjudication, 6 L. \& HuM. BEHAV. 121, 122-25 (1982) (parsing the "dispute resolution model" and the "structural reform" model); Kenneth E. Scott, Two Models of the Civil Process, 27 Stan. L. Rev. 937, 937-39 (1975) (distinguishing the "Conflict Resolution Model" and the "Behavior Modification Model").

187. See Chayes, supra note 186 , at $1282-84$.

188. See id. at $1282-84,1302$. 
ascertainability and limited cy pres with the private law model, and then shows that modern litigation better fits the public law model, which supports a more liberal approach. Thus, the legitimacy critique fails because its private-law-model premise fails.

Although this line of reasoning highlights an important aspect of the problem - the debate over strict ascertainability and cy pres is a debate over the regulatory function of civil adjudication - it fails as an adequate response to the legitimacy argument. Proponents of strict ascertainability and limited cy pres need not subscribe to the private law model. They can accept some forms of public law litigation, yet still worry about whether courts should be handling anonymous, public-interest-centered, attorney-driven class actions that focus on deterrence without much concern for redressing class members' individual claims of right. More generally, as I have explained elsewhere, the private-law/public-law dichotomy oversimplifies litigation and lacks sufficient normative content to be able to say much at all about what courts should and should not be doing. ${ }^{189}$

What is needed is a normative argument that focuses on the specific features that make small-claim class actions with weak ascertainability and liberal use of cy pres so troubling. These are: (1) the anonymity, indeed virtual irrelevance, of the plaintiff right holders, and (2) the almost exclusive focus on deterrence without any substantial interest in compensating class members. The first feature prompts the move to strict ascertainability, and the second motivates restrictions on cy pres. These two features are troubling because they thrust the regulatory dimension of small-claim class actions to the forefront and push the remedial dimension to the background. The anonymity of class members highlights the fact that the litigation is not really about individual right holders, and the cy pres remedy makes clear that the real focus is deterrence, not compensation.

To determine whether class actions with these two features are legitimate, we need a normative theory of adjudicative legitimacy. Moreover, any such theory must account for the settled principles and practices of contemporary adjudication. The idea is to construct a reasonably coherent set of general principles that fit with the settled aspects of litigation practice in an attractive way. ${ }^{190}$ This is a challenging task.

189. Robert G. Bone, Lon Fuller's Theory of Adjudication and the False Dichotomy Between Dispute Resolution and Public Law Models of Litigation, 75 B.U. L. REV. 1273 (1995).

190. I have in mind a constructivist approach that closely resembles Ronald Dworkin's interpretive theory and has much in common with John Rawls's idea of reflective equilibrium. See RONALD DWORKIN, LAW'S EMPIRE 225-27 (1986) (describing a process of legal reasoning grounded in an effort to form "the best constructive interpretation of the community's legal practice"). See generally JOHN RAWLS, A THEORY OF JUSTICE 17-19 (rev. ed. 1999) (describing the process of seeking a reflective equilibrium). 
Fortunately, there is a second-best approach that is easier to implement. The idea is to identify well-settled aspects of litigation practice that have elements similar to the litigation elements that are so troubling-here, anonymous plaintiffs and a dominant deterrence focus-and then see whether the policies that justify those well-settled elements can be extended to justify the comparable elements in small-claim damages class actions. In other words, the approach I will use here looks for analogies in the way our adjudication system already tolerates anonymity and prioritizes deterrence, and then compares those analogies to the problematic class action features.

\section{B. The Punitive Damages Analogy}

Punitive damages might seem a promising place to begin. ${ }^{191}$ This form of relief serves deterrence and retributive goals rather than compensation and aims to benefit the public at large, not the individual plaintiff. ${ }^{192}$ However, the analogy is not close enough.

Unlike small-claim class actions with only weak ascertainability, lawsuits for punitive damages have identifiable plaintiffs. Moreover, the punitive damage award is ordinarily paid to the plaintiff whose rights have been violated and not, as in cy pres, to a third party. ${ }^{193}$ Indeed, courts tend to treat punitives as ancillary to compensation; usually they award punitive damages only when the plaintiff is also entitled to compensatory relief. ${ }^{194}$

191. Professor Myriam Gilles does a good job of developing this analogy. Gilles, supra note 5, at 323-27.

192. Some law-and-economics scholars argue that punitive damages help to offset systematic shortcomings in compensatory damage awards. See, e.g., A. Mitchell Polinsky \& Steven Shavell, Punitive Damages, in TORT LAW AND ECONOMICS 228 (Michael G. Faure, ed. 2009). Still, for these scholars, deterrence remains the central goal (along with punishment). For example, awarding punitive damages can improve deterrence by correcting for under-enforcement and for the exclusion of certain types of harm from the compensatory award. Id. at 231-33.

193. Although some states require a portion of the punitive award be paid to the state rather than to the plaintiff. See Gilles, supra note 5, at 324.

194. See, e.g., Wolff v. Berkley Inc., 938 F.2d 100, 102-03 (8th Cir. 1991) (refusing an award of punitive damages under Iowa law when compensatory damages for emotional harm were unavailable as a matter of law, noting that "[p] unitive damages are incidental to the main cause of action, and must be reasonably proportionate to the harm suffered"); Lowell Staats Mining Co., Inc. v. Pioneer Uravan, Inc., 878 F.2d 1259, 1267 (10th Cir. 1989) (holding under Colorado law that "[f]ailure to prove the existence of actual damages means that no punitive damages may be recovered"). Even for intentional tort claims involving nominal and punitive damages, "the nominal damage award represents the recognition that, although immeasurable in mere dollars, actual harm has occurred." Jacque v. Steenberg Homes, Inc., 563 N.W.2d 154, 160 (Wis. 1997) (allowing $\$ 100,000$ punitive-damage award to rest on nominal damages awarded for intentional trespass to land). The exceptions are civil rights claims. See, e.g., Abner v. Kan. City S. R.R. Co., 513 F.3d 154, 160 (5th Cir. 2008) ("We agree with the conclusion of several of our sister circuits that a punitive damages award under Title VII and $\S 1981$ need not be accompanied by compensatory damages. We base our holding on the language of the statute, its provision of a cap, and the purpose 
And under current Supreme Court jurisprudence at least, punitive damages are supposed to focus on plaintiff-specific facts, such as the magnitude of the plaintiff's loss and the nature of the defendant's actions toward the particular plaintiff. ${ }^{195}$ Thus, lawsuits for punitive damages do not exhibit the degree of anonymity and the narrow deterrence focus that cast doubt on the legitimacy of small-claim class actions.

\section{The 23(b)(2) Analogy}

There is, however, a more promising analogy: the Rule 23(b)(2) class action for injunctive relief. ${ }^{196}$ Invoking (b)(2) in this way may seem odd to some readers. After all, the (b)(2) class action involves a group-based wrong and classwide, group-based relief, whereas the (b)(3) damages class, at least paradigmatically, involves an individualized wrong and individual relief. However, the analogy is much closer than it seems at first glance. When a statute creates a damages claim and the claim prioritizes deterrence as a policy goal, the superficial structural differences between (b)(2) and (b)(3) give way to a deeper functional convergence. A (b)(3) class action enforcing a deterrence-based claim has many of the same group characteristics as a (b)(2) class action.

Let me be clear. I am not suggesting that a small-claim class action for damages can be certified under 23(b)(2). The (b)(2) provision is reserved for lawsuits seeking classwide injunctive or declaratory relief. Rather, my point is that the functional similarities between the two types of class action justify a similar approach to both. This is important because, as I explain

of punitive damages under Title VII.").

195. See Phillip Morris USA v. Williams, 549 U.S. 346, 353-54 (2007); State Farm Mut. Auto. Ins. Co. v. Campbell, 538 U.S. 408, 416, 418 (2003). But see Gilles, supra note 5, at 324-27 (arguing that punitive damages have always fit more comfortably with a public law model, but that recent Supreme Court decisions reflect discomfort with the public-law deterrence goal and have tried to squeeze punitives into a private law model).

196. The 23(b)(2) class action is the most useful analogy because it is the most proximate to the small-claim damages class action. However, there is a more general class of litigation that is also helpful: the private attorney general suit. See William B. Rubenstein, On What a "Private Attorney General" Is - And Why It Matters, 57 VAND. L. REV. 2129, 2133-37 (2004). The institution of the private attorney general relies on private litigation to further the public interest. See generally Zachary D. Clopton, Redundant Public-Private Enforcement, 69 VAND. L. REV. 285, 294-99 (2016) (describing public claims brought by private parties and hybrid claims that combine public and private features). For example, an attorney who represents a civil rights plaintiff might seek a broad civil rights injunction that serves the public interest as well as the private interest of her client-and possibly even do so with a 23(b)(2) class action. Moreover, the citizen suit provisions of many environmental statutes empower private parties to vindicate the public interest in environmental quality by seeking injunctive relief and penalties. $I d$. at 294 . In these cases, the real beneficiaries of the lawsuit are anonymous members of the public and the primary goal is deter wrongdoing rather than compensate victims. 
below, even the strongest advocates of strict ascertainability refuse to apply it to $(\mathrm{b})(2)$ class actions. ${ }^{197}$

The analogy to (b)(2) class actions, if successful, has another important advantage. To recall, we are looking for a procedure that has elements similar to the two elements that worry us in small-claim class actionsanonymous plaintiffs and a deterrence focus-and is also a well-settled aspect of litigation practice. The (b)(2) class action satisfies the second condition. As I have explained elsewhere, this type of class action is well established. ${ }^{198}$ Its roots trace back to the public-right representative suit of the nineteenth century, and even further back to the general-right representative suits in seventeenth and eighteenth century England. ${ }^{199}$

\section{Construing the Statutory Claim: Deterrence Versus Compensation}

The (b)(2) analogy works only if the private claim for damages serves the primary purpose of deterring wrongful conduct rather than compensating victims for their losses. Whether a claim should be understood in this way depends on the best interpretation of the statute creating the claim. There are a number of statutory claims that fit this profile, including consumer protection and antitrust claims that allow individuals to sue for compensation when they suffer only small harms. ${ }^{200}$

It is important to bear in mind that a legal right to compensation need not necessarily have the ultimate goal of compensating victims for their losses. A legislature can create a right to compensation for the primary purpose of deterring wrongful conduct ex ante rather than remedying losses ex post. ${ }^{201}$ In fact, "compensation" simply describes a practice of transferring wealth from a defendant injurer to an injured plaintiff. To justify such a practice, one needs a normative theory that explains why the transfer should take place. That theory might be deontological, in which case the normative goal would be to compensate for the victim's harm. An example is the familiar theory of corrective justice, which holds that a

197. See, e.g., Shelton v. Bledsoe, 775 F.3d 554 (3d Cir. 2015).

198. See Bone, Personal and Impersonal, supra note 20, at 249-50, 272-75, 297-98.

199. Id. Like the (b)(2) class action, these earlier representative suits focused on the class qua class, redressed class-based wrongs and granted class-based remedies, and automatically bound all class members without giving them a chance to exit the class or litigate on their own. Id.

200. See, e.g., Fair Debt Collection Practices Act, 15 U.S.C. § 1692k (2012); Telephone Consumer Protection Act, 47 U.S.C. § 227 (2012); Clayton Act, 15 U.S.C. $§ 15$ (2012); see also Gilles \& Friedman, supra note 89, at 105-07, 132-36 (arguing that the best account of the small claim class action for many statutory claims is that it enables deterrence, not compensation).

201. Professor Redish misses this point when he argues that cy pres violates the Rules Enabling Act and separation-of-powers principles. See Redish et al., supra note 8, at 646. 
wrongdoer has a moral duty to restore the equilibrium that its wrongful act disturbed. ${ }^{202}$

However, consumer protection, antitrust, and other regulatory statutes fit the deontological paradigm very poorly. They are better understood as implementing consequentialist values; in particular, they grant compensatory remedies for small losses in order to deter future wrongful conduct. The proscribed conduct might be wrongful for moral or for economic reasons, but the goal is the same - to deter the conduct ex ante rather than redress its harms ex post. Faced with the prospect of private lawsuits seeking compensation, a potential wrongdoer expects to pay for the harm it causes, and as a result should strike its own private cost-benefit balance in a way that encourages compliance with the statutory duty. ${ }^{203}$

\section{The 23(b)(2) Analogy}

To recall, we are looking for a well-settled litigation practice that features anonymous plaintiffs and a dominant deterrence or regulatory focus. The 23(b)(2) class action has both elements. Rule 23(b)(2) authorizes a class action when "the party opposing the class has acted or refused to act on grounds that apply generally to the class, so that final injunctive relief or corresponding declaratory relief is appropriate respecting the class as a whole." ${ }^{204}$ The 1966 Advisory Committee created (b)(2) class actions with school desegregation and other civil rights suits foremost in mind. ${ }^{205}$ These suits typically involve classes defined by group characteristics, and remedies that directly benefit the group qua group and benefit individuals only indirectly as members of the group.

For example, a suit seeking an injunction ordering desegregation of a school district features a group-based wrong and a group remedy; neither wrong nor remedy singles out individual class members in any personal way. The named plaintiffs allege that the school district discriminated on the basis of race, a common group characteristic, and thus, as (b)(2) puts it, "acted or refused to act on grounds that apply generally to the class." They seek an injunctive remedy that targets this group-based wrong, an injunction "respecting the class as a whole," to use the language of (b)(2). The identities of particular African-American students who happen to be attending the targeted schools at the time of the suit do not matter legally.

202. See, e.g., Ernest J. Weinrib, Understanding Tort Law, 23 VAL. U. L. ReV. 485, 524 (1989).

203. Compensation can also provide an insurance benefit, but that benefit is insignificant for very small claims. See Fitzpatrick, supra note 105, at 2069-70.

204. FED. R. CIV. P. 23(b)

205. Marcus, supra note 30, at 695-96. 
What matters is the class as a group-all African-American students attending district schools currently or at any time in the future.

It is this group quality and impersonal character that explain why strict ascertainability is not necessary to certification of a (b)(2) class action. ${ }^{206}$ In Shelton v. Bledsoe, for example, the plaintiff brought a (b)(2) class action for injunctive relief on behalf of prisoners in a maximum security prison. ${ }^{207} \mathrm{He}$ defined the class as "[a]11 persons who are currently or will be imprisoned in the SMU program at USP Lewisburg." "208 The district court denied certification on the ground that the class failed to meet the strict ascertainability requirement. ${ }^{209}$ The Third Circuit reversed, holding that strict ascertainability is not necessary to a (b)(2) class action. ${ }^{210}$ The Court noted that "the key" to the (b)(2) class is the "indivisible" nature of the remedy: the injunctive or declaratory relief must apply to the class as whole and cannot be crafted differently for individual class members. ${ }^{211}$ It then reasoned as follows:

Because the focus in a (b)(2) class is more heavily placed on the nature of the remedy sought, and because a remedy obtained by one member will naturally affect the others, the identities of individual class members are less critical in a (b)(2) action than in a (b)(3) action. See Wal-Mart, 131 S. Ct. at 2558 ("When a class seeks an indivisible injunction benefitting all its members at once, there is no reason to undertake a case-specific inquiry into whether class issues predominate or whether class action is a superior method of adjudicating the dispute."); Barnes, 161 F.3d at 143 n. 18 ("Injuries remedied through (b)(2) actions are really group, as opposed to individual injuries." (citation omitted)).

Thus, the core reason for relieving (b)(2) class actions from the strict ascertainability requirement has to do with the group nature of the lawsuit. Small-claim class actions aimed at deterrence share this group quality, and it is this common feature that justifies exempting those class actions from strict ascertainability as well. For both types of litigation, the wrongful acts and

\footnotetext{
206. For an overview of the case law, see 2 NEWBERG ON ClASS ACTIONS, supra note 48 , $\S 3: 7$.

207. Shelton v. Bledsoe, 775 F.3d 554, 557 (3d Cir. 2015).

208. Id. at 558 .

209. Id. at 559 .

210. Id. at 563

211. Id. at 561

212. Id. The Court also mentioned functional reasons for the different treatment, such as the fact that there is no reason to give notice for opt out purposes and the injunctive relief does not require any distribution to the class. Id. at 561-62. However, the group nature of the lawsuit is still central; indeed, it is the reason why opt out rights are not given and why injunctive relief is classwide and not individualized.
} 
the relief sought focus on a group, not on individuals within that group - and the group focus makes it legitimate to proceed despite the inability to identify individual class members.

First, consider the nature of the wrong in both cases. In a (b)(2) class action, the defendant must have acted toward the class as a group without singling out any class member for individual treatment. ${ }^{213}$ The same is true for most of the (b)(3) class actions. In Carrera v. Bayer Corp., for example, Bayer did not single out any individual consumer. It communicated its supposedly deceptive advertising in a uniform way to consumers as a group. $^{214}$

Second, the remedial right and the relief requested are group-focused. In a (b)(2) class action, class members matter not as individuals, but as holders of the particular group-based characteristics that the substantive law identifies as salient and that define the class. The injunctive relief directly benefits the group qua group and therefore indirectly benefits anyone who happens to possess the group-based characteristics that define the class. This is why it does not matter that the plaintiffs are anonymous; their individual identities are not legally significant.

For example, the class in the Shelton case consisted of anyone occupying the status of "prisoner," and the injunctive relief requested sought to modify the defendant's conduct toward prisoners in general, not toward any particular prisoner. As another example, consider a (b)(2) class action alleging racial discrimination against African-American employees. An injunction eliminating the racially discriminatory employment practice does not provide relief directly to individual employees; rather, it restructures the defendant's employment practices so that all current and future AfricanAmerican employees benefit by virtue of their being members of the racial group. Indeed, in theory at least, an injunction would still make sense even if all current employees happened to quit at the time the injunction was entered and a new set of employees was hired - since the target is the group and that group includes new as well as current employees.

The same is true for small-claim class actions aimed at deterrence. In the Carrera case, for example, the legal claim treated consumers as a homogenous group. The damages remedy was formally individualized, of course, but it was functionally collective insofar as its goal was to promote

213. For example, the Shelton plaintiff alleged that prison officials had a general policy of housing violent prisoners and applied the policy uniformly, violating the Eighth Amendment guarantee against cruel and unusual punishment. Id. at 557-58.

214. Carrera v. Bayer Corp., 727 F.3d 300, 305-06 (3d Cir. 2013). 
general deterrence. In a case like this, what matters from a legal perspective is the aggregate recovery, not any consumer's individual share. ${ }^{215}$

Indeed, there is a kind of functional equivalence between damages and injunctive relief in a consumer fraud case like Carrera. To see this point, note that the deterrence goal furthered by awarding damages might also have been achieved by an injunction ordering Bayer to set up an independent oversight committee to review all its future ads. If this injunction approach were legally available, a (b)(2) class action could probably have been certified, and in that case there would have been no strict ascertainability requirement. Of course, an injunctive remedy of this sort is not available for this type of case - and maybe for good reason. The choice of damages instead of an injunction minimizes judicial intrusion into the marketplace and incentivizes sellers to figure out the optimal approach, thereby enlisting the seller's superior information. But the damages remedy is not fundamentally different from our hypothetical injunction at the policy level. The deterrence goal is the same. And the damages remedy, like the hypothetical injunction, benefits the class as a whole, not class members as individuals.

These similarities have strong implications for strict ascertainability. Although monetary relief is divisible as a formal matter, it is indivisible as a functional matter when its purpose is to deter. General deterrence is a public good, and it is not possible to divide it into individual shares. Therefore, just as the indivisible nature of the group remedy in a (b)(2) suit justifies exempting (b)(2) class actions from strict ascertainability, so too the indivisible nature of deterrence-oriented damages justifies exempting (b)(3) small-claim class actions from strict ascertainability. In each case, class members are not relevant, so there is no legitimacy-based reason for class members to be identifiable.

The (b)(2) analogy also has implications for the use of cy pres. Insofar as general deterrence is the primary goal, it should not matter from a legitimacy perspective whether individual members of the class benefit from an aggregate settlement, any more than it matters whether current employees benefit from a (b)(2) injunction eliminating discriminatory employment practices. In both cases, the benefit that individuals receive flows indirectly from the benefit the group qua group receives.

215. Nor should it matter that some class members have suffered no legal injury. This follows for a (b)(2) class action from the irrelevance of class members as individuals and the focus on the defendant's acts toward the class qua class. The same should also be true for a small-claim class action, and for the same reason. 
However, the (b)(2) analogy also implies a limitation on cy pres. A judge is not supposed to use a (b)(2) class action as an excuse to clean up the defendant's practices in general. Nor is it proper for the judge to slip into the injunction a provision that benefits a third party who has no connection to the lawsuit. The injunctive relief must be related to the legal wrong. How tight that relationship should be is a matter of some controversy, but everyone agrees that the injunction must at least promote the goals of the substantive law. The same limitation should apply to cy pres. While deterrence demands only that the defendant pay aggregate damages, adjudicative legitimacy demands more: the third party who receives the settlement funds must be likely to use those funds to further the goals of the substantive law. ${ }^{216}$

Still, this requirement can be quite flexible. Some courts insist on a rather tight nexus between cy pres beneficiary and substantive law: settlement funds must be distributed to the "next-best" recipient after distribution to the class. ${ }^{217}$ The ALI's Principles of the Law of Aggregate Litigation adopts a looser requirement: the cy pres beneficiary must only have interests that "reasonably approximate those being pursued by the class." ${ }^{218}$ Many courts follow the ALI's more flexible approach, ${ }^{219}$ and the analogy with (b)(2) supports doing so. The idea is to choose a cy pres beneficiary who will advance the goals of the substantive law. This can be accomplished without a particularly tight connection between beneficiary and substantive claim. How tight a connection should depend, among other things, on the cost of identifying a superior candidate. Just as the court has broad discretion to fashion an injunction in a (b)(2) suit, so too the court should have broad discretion to choose (and approve) a cy pres beneficiary.

216. In fact, one can make a case for distributing all of the funds to a third party and none to class members, given that the third party is more likely to benefit the class as a whole. However, this is inappropriate when, as is usually the case, the substantive law selects compensation as the means to achieve deterrence.

217. See In re BankAmerica Corp. Sec. Litig., 775 F.3d 1060, 1067 (8th Cir. 2015).

218. ALI PRINCIPLES, supra note 145, § 3.07(c).

219. See, e.g., In re Lupron Mktg. \& Sales Practice Litig., 677 F.3d 21, 33 (1st Cir. 2012) (adopting the "reasonable approximation' test"); In re Citigroup Inc. Secs. Litig., No. 07-CV-9901, 2016 WL 4198194, at *4-6 (S.D.N.Y. Aug. 9, 2016) (rejecting the "rigid and overly restrictive" next-best standard in favor of the ALI's more flexible reasonable approximation test). The Ninth Circuit formulates the standard in terms of a "substantial nexus" between the cy pres distribution and the interests of class members in light of "the nature of the plaintiffs" lawsuit, the objectives of the underlying statutes, and the interests of the silent class members." Lane v. Facebook, Inc., 696 F.3d 811, 821 (9th Cir. 2012) (noting that settling parties need not select an "ideal" cy pres recipient, since that degree of intrusion into private parties' negotiations would be undesirable). 


\section{CONCLUSION}

This Article began by calling for a return to the functional vision of the 1966 Rule 23 revision. Over the past twenty years, federal courts have departed from this vision and significantly limited the class action in ways that are difficult to justify on functional grounds. Strict ascertainability and limitations on cy pres are notable examples. Supporters of these restrictive doctrines defend them with functional arguments, but those arguments fail in rather obvious ways. Nevertheless, these supporters have a point, but only if their objections are understood in legitimacy, not functional, terms. If there is a reason to worry about class actions with anonymous class members and a primary focus on deterrence, it can only be because these class actions are inconsistent with conditions for adjudicative legitimacy.

However, the legitimacy critique does not survive close analysis. A small-claim class action used to enforce a statutory cause of action that prioritizes deterrence is very similar to a (b)(2) class action for classwide injunctive relief. And those similarities support the legitimacy of weak ascertainability and liberal use of cy pres. With legitimacy satisfied, rules governing ascertainability and cy pres should be evaluated only on functional grounds, in keeping with the functional vision that animated the 1966 revision. And a functional analysis does not support a restrictive approach.

This Article also makes a more general point. All too often, the contending sides in class action debates frame their arguments in functional terms when the debate is better pitched at the level of legitimacy. This mismatch confuses the normative stakes and frustrates efforts to find common ground. If legitimacy is the issue, then legitimacy should be the focus. Debating the merits in legitimacy terms, however, is not an easy thing to do; it requires a normative account of the necessary conditions for adjudicative legitimacy, and constructing such an account is a challenging task. Still, we have no choice but to meet the challenge squarely if we want to make substantial progress in designing a fair, just, and efficient procedural system. 